\title{
On the origins of entrepreneurship: Evidence from sibling correlations $^{\text {th }}$
}

\author{
Theodor Vladasel ${ }^{\mathrm{a}, *}$, Matthew J. Lindquist ${ }^{\mathrm{b}}$, Joeri Sol ${ }^{\mathrm{c}}$, Mirjam van Praag \\ ${ }^{a}$ Universitat Pompeu Fabra, Barcelona GSE, Spain \\ ${ }^{\mathrm{b}}$ Swedish Institute for Social Research (SOFI), Stockholm University, Sweden \\ ${ }^{\mathrm{c}}$ University of Amsterdam, TI, the Netherlands \\ ${ }^{\mathrm{d}}$ Vrije Universiteit Amsterdam, Copenhagen Business School, CEPR, IZA, TI, the Netherlands
}

\section{A R T I C L E I N F O}

\section{Keywords:}

Entrepreneurship

Self-employment

Family background

Sibling correlations

\begin{abstract}
A B S T R A C T
Despite the consensus that entrepreneurship runs in the family, we lack evidence regarding the total importance of family and community background, as well as the relative importance of different background influences that affect entrepreneurship. We draw on human capital formation theories to argue that families and communities provide a salient context for the development of individual entrepreneurial skills and preferences, beyond the existing focus on parental entrepreneurship. We posit that early influences are more important than later influences and propose a hierarchy of family influences, whereby genes have the largest explanatory power, followed by parental entrepreneurship, neighborhoods, and parental resources, and finally by parental immigration, family structure, and sibling peers. Finally, we argue that the higher human and financial capital intensity of incorporated relative to unincorporated entrepreneurship predictably alters the hierarchy of family influences, as does gender. Sibling correlations estimated on Swedish register data confirm our hypotheses.
\end{abstract}

\section{Executive summary}

When and how entrepreneurial skills and preferences form are important questions for prospective entrepreneurs, researchers, and policy makers alike. It is not yet clear, for example, whether influences later in life can compensate for the absence of earlier investments (such as transfers of relevant human capital) and experiences in determining entrepreneurship, or whether early influences are crucial. While the contexts people encounter as adults - neighborhoods, universities, or organizations - act as fonts of entrepreneurship, individuals' prior choice to be in these environments explains most of the subsequent occupational choice. Moreover, entrepreneurship education programs work better with younger, rather than older students. Together, these results suggest that an investigation into the origins of entrepreneurship should focus on the early stage of individuals' lives.

\footnotetext{
We thank the editor (Justin W. Webb), the two anonymous reviewers, seminar and workshop participants at Universitat Pompeu Fabra, Bocconi University, Imperial College Business School, Copenhagen Business School, Stockholm University, Universidad Carlos III Madrid, Barcelona Graduate School of Economics, DRUID, the 3rd CEPR Workshop on Entrepreneurship Economics, the 24th CCC Doctoral Conference, the 2017 Academy of Management Meeting, the Spring Meeting of Young Economists (Lisbon), the Applied Economics Meeting (Sevilla), the 8th SEI Doctoral Consortium, as well as Anders Björklund, Saul Estrin, April Franco, Markus Jäntti, Laura Rosendahl-Huber, and Henry Sauermann for many insightful comments. Lindquist gratefully acknowledges funding from the Swedish Research Council (Vetenskapsrådet 2017-01941).

* Corresponding author.

E-mail addresses: theodor.vladasel@upf.edu (T. Vladasel), matthew.lindquist@sofi.su.se (M.J. Lindquist), J.Sol@uva.nl (J. Sol), mvp.si@cbs.dk (M. van Praag).
} 
We propose that family and community background provide a salient context for the formation of entrepreneurial skills and preferences, but whose total importance for entrepreneurship is still unclear. Our core argument is that the influence of families and communities goes beyond an overly narrow focus on parental entrepreneurship and role models, as they provide a plethora of influences on children's decisions to become entrepreneurs. Parents transfer genes conducive to entrepreneurship, provide financial resources, business - or industry - specific knowledge, a cultural inheritance and values, and influence entrepreneurship through location choices.

To rank family influences in entrepreneurship by their relative importance, we draw on recent human capital accumulation theories, whereby human capital is more malleable early in life and the productivity of later influences rises with the presence of early influences. So, the earlier an individual is exposed to an influence, the larger the importance of that influence. We propose a 'hierarchy of family influences', where genes have the largest explanatory power, followed by parental entrepreneurship, neighborhoods, and parental resources, and finally by parental immigration, family structure, and sibling peers. This hierarchy varies somewhat with gender, as well as the type of entrepreneurship, since incorporated firms have larger human and financial capital requirements than unincorporated firms.

We test our hypotheses in a sample of almost 700,000 individuals born between 1960 and 1970 in Sweden. Unlike previous studies comparing the outcomes of parents to those of their offspring, our empirical approach relies on comparing the outcomes of children in the same family. 'Sibling correlations' have the advantage of capturing all the influences that siblings share, providing us with an estimate for the total importance of family and community background. They are also flexible enough to allow us to account for different family influences, providing an estimate for their relative importance. We find strong empirical evidence for our arguments.

Our study demonstrates the value of taking a broader view of the importance of families, beyond parental entrepreneurship. Family and community background explain almost half of the variation in entrepreneurship outcomes and contribute to the development of entrepreneurial human capital at key early stages of individuals' lives. Shared genes explain roughly half of the importance of background, but children also learn from entrepreneurial role models inside and outside the household, and rely on families for resources. Additional nuance arises from our separate study of different types of entrepreneurship: not only do families matter more for incorporation, but the latter also responds strongly to the availability of parental resources, incorporation-specific role models, as well as the accumulation of leadership skills. Thus, the type of entrepreneurship matters both theoretically and empirically.

Several practical lessons emerge from our study. For example, entrepreneurial careers could be highlighted at an early age, giving prospective entrepreneurs the time to make concerted investments into their human capital. Entrepreneurship education programs can also exploit the importance of early influences and target younger students for higher effectiveness. Both these strategies could emphasize the development of leadership skills, thus fostering the growth-oriented incorporated entrepreneurship that has higher odds of delivering the innovation, job creation, and growth usually associated with entrepreneurship.

\section{Introduction}

Entrepreneurship is often hailed as a driver of innovation, job creation, and growth. However, the origins of entrepreneurial behavior are not yet fully understood. Individual preferences, ability, education, and financial resources, all feature as potential dispositional determinants of entrepreneurship (Parker, 2009). More recently, the influences of universities, organizations, or neighborhoods have also been studied. While each of these contextual effects has been convincingly documented, they stem partly from the selection of individuals into such environments, based on ability and preferences (Özcan and Reichstein, 2009; Elfenbein et al., 2010; Roach and Sauermann, 2015; Tåg et al., 2016). This implies that the origins of entrepreneurial behavior should be investigated at an earlier stage in individuals' lives.

We argue (along with many others) that families and communities provide a particularly salient context for the formation of entrepreneurial skills and preferences. A large body of evidence supports the claim that 'entrepreneurship runs in the family': children of entrepreneurs are $30 \%$ to $300 \%$ more likely to become entrepreneurs themselves relative to children of non-entrepreneurs (Parker, 2009). ${ }^{1}$ Yet despite this consensus, we still lack evidence concerning the total importance of family and community influences, as well as the relative importance of different background factors that determine entrepreneurship.

In this paper, we use sibling correlations to assess how much of the variation in entrepreneurship outcomes is explained by family and community background, as well as to disentangle the contributions of individual influences, including but not limited to parental entrepreneurship. To guide our empirical analysis, we draw on new theories of human capital formation with dynamic complementarities (Cunha and Heckman, 2007, 2008; Cunha et al., 2010) and argue that the relative importance of family and community influences closely matches their timing, such that early influences prove more important than later influences for individuals' entrepreneurship outcomes. Furthermore, we distinguish between small scale, unincorporated entrepreneurship and growth oriented, incorporated entrepreneurship (Levine and Rubinstein, 2018; Henrekson and Sanandaji, 2019), types of entrepreneurship that require different bundles of resources and draw on different family and community influences. Finally, as men and women differ in

\footnotetext{
${ }^{1}$ This result is remarkably robust across countries and time (Lentz and Laband, 1990; Aldrich et al., 1998; Blanchflower and Oswald, 1998; Fairlie, 1999; Dunn and Holtz-Eakin, 2000; Arum and Müller, 2004; Niittykangas and Tervo, 2005; Aldrich and Kim, 2007; Fairlie and Robb, 2007a, 2007b; Sørensen, 2007; Colombier and Masclet, 2008; Andersson and Hammarstedt, 2010, 2011; Laspita et al., 2012; Hoffmann et al., 2015; Lindquist et al., 2015; Edelman et al., 2016; Criaco et al., 2017; Hopp et al., 2019).
} 
their response to family and community influences in entrepreneurship (Parker, 2009), we also theorize about the effect of gender on sibling correlations and the background factors driving them.

In our empirical analysis, we use a variance decomposition technique to estimate sibling correlations. Intuitively, sibling correlations capture the degree to which children in the same family are more similar in their entrepreneurial behavior than randomly drawn individuals from the population: the more important shared family and community influences are, the larger sibling correlations will be. Sibling correlations can be thought of as omnibus measures that capture shared family-wide influences, such as parental entrepreneurship, income, and aspirations, cultural inheritance, and genes, as well as shared influences not directly experienced in the home, such as schools, churches, and neighborhoods. Sibling correlations thus give a more comprehensive measure of the importance of family influences than intergenerational correlations (Solon, 1999; Black and Devereux, 2011). We also extend the sibling approach in ways that allow us to assess the contribution of each hypothesized family and community influence to our estimates of sibling correlations, thereby testing our hierarchy of family influences.

To compute sibling correlations in entrepreneurship, we use detailed Swedish register data, including nearly 700,000 children born between 1960 and 1970. For the years 1993-2012 we have information from the Swedish tax authority concerning unincorporated and incorporated firm ownership for all these individuals and their parents. We also have extensive data on individual and family socio-economic variables, including education, income, family structure, immigration status, and parish of residence, as well as cognitive and non-cognitive skills (for men). The estimated sibling correlations strongly support our hypotheses.

Our paper makes several key contributions. First, we introduce a novel focus on the total importance of family and community influences for entrepreneurship. Specifically, we provide a unified theoretical and empirical framework for integrating a set of channels known to affect entrepreneurial entry and performance, allowing us to argue that the importance of families for new venture creation extends far beyond a narrow focus on parental entrepreneurship. Relative to previously estimated parent-offspring correlations (Dunn and Holtz-Eakin, 2000; Sørensen, 2007; Laspita et al., 2012; Lindquist et al., 2015), sibling correlations capture all of the influences, both observed and unobserved, that children in a family share. More precisely, the total influence of families is several times larger than the importance of parental entrepreneurship by itself, supporting the predicted large salience of the family context for the formation of entrepreneurial skills and preferences. They also clearly demonstrate how parental entrepreneurship is only one of several family influences that determine entrepreneurship, albeit an important one.

Second, we draw on human capital accumulation theories to argue for a hierarchy of family influences in entrepreneurship, whereas previous work has largely analyzed such factors separately (Holtz-Eakin et al., 1994a; Blanchflower and Oswald, 1998; Hout and Rosen, 2000; Nicolaou et al., 2008; Pistaferri et al., 2020). We posit that the relative importance of family and community influences for the formation of entrepreneurial skills and preferences will parallel the timing and extent of children's exposure to these influences. In other words, the earlier and longer an individual is exposed to a given background factor, the higher the share of sibling similarity this factor explains. Our theoretical arguments receive support in the data, with shared genes - the earliest and longest lasting factor - explaining about half of sibling correlations. Early influences such as parental entrepreneurship, neighborhoods, and parental resources explain roughly $10 \%$ of sibling correlations. Later influences such as parental immigration, family structure, and sibling peers explain $<1 \%$ of the total importance of background.

Third, we add to the debate on defining entrepreneurs by showing how our hierarchy of influences varies with the type of entrepreneurship (Hurst and Pugsley, 2011; Henrekson and Sanandaji, 2014; Levine and Rubinstein, 2017, 2018). Unincorporated firms require less human and financial capital than incorporated firms, such that families can affect the latter through more channels. Sibling correlations in incorporation are accordingly higher than those in unincorporated outcomes. Parental incorporation is a strong predictor of individual incorporation, suggesting that role models in entrepreneurship are type-specific. Moreover, parental resources explain a higher share of sibling correlations in incorporation, reinforcing the capital intensive nature of this type of entrepreneurship; this effect is more pronounced for women, pointing towards the higher financial hurdles to entry women face. Incorporated entrepreneurs' task content and management requirements further explain the strong effects of leadership skills on incorporated entry and performance. By contrast, neighborhoods have substantial explanatory power for men's unincorporated entrepreneurship, which may be driven by male-dominated, geographically-concentrated professions often pursued through unincorporated firms. Thus, the definition of an entrepreneur matters - both in theory and in practice.

\section{A hierarchy of family influences in entrepreneurship}

Entrepreneurship represents a resource-dependent occupation, requiring substantial amounts of human, social, and financial capital for entry and success (Levine and Rubinstein, 2017). These resources are often built with the help of families, through investments and interactions that shape entrepreneurial human capital (Parker, 2009). Parents can serve as role models (Sørensen, 2007; Hoffmann et al., 2015), transfer genes conducive to entrepreneurship (Nicolaou et al., 2008; Lindquist et al., 2015), provide financial resources (Holtz-Eakin et al., 1994a, 1994b; Blanchflower and Oswald, 1998), business- or industry-specific knowledge (Hvide and Oyer, 2018), a cultural inheritance and entrepreneurial values (Hout and Rosen, 2000; Halaby, 2003; Laspita et al., 2012), and influence entrepreneurship through neighborhood choice (Pistaferri et al., 2020). Thus, families represent a particularly salient context for shaping individuals' entrepreneurial skills and preferences. Our baseline expectation is that:

Hypothesis 1. Family and community background explain a substantial share of variation in individuals' entrepreneurship outcomes.

To build insight into the relative importance of elements that compose the explanatory power of families, we draw on human capital accumulation theories positing a strong impact of early life influences (Cunha and Heckman, 2007, 2008). That is, the sooner and longer an individual is exposed to an investment or experience, the larger will be the contribution of that influence to their 
human capital formation (Cunha et al., 2010). ${ }^{2}$ For example, entrepreneurship education has been shown to influence the entrepreneurial skills and future performance (Huber et al., 2014; Elert et al., 2015) of pupils in their early teens, but not of individuals in tertiary education or adults (Oosterbeek et al., 2010; Fairlie et al., 2015). Children exposed to entrepreneurial role models at home and in the community earlier in life are also more likely to become entrepreneurs (Sørensen, 2007; Pistaferri et al., 2020). Moreover, studies of contextual effects in entrepreneurship stemming from universities, communities, or organizations find a strong role for predisposition: selection into an environment conducive to entrepreneurship appears to be more important than the treatment effects of that environment for individuals' subsequent entrepreneurial outcomes (Özcan and Reichstein, 2009; Elfenbein et al., 2010; Roach and Sauermann, 2015; Tåg et al., 2016). Together, these results suggest that the chronological sequence of influences that siblings share provides a helpful starting point for our inquiry into background factors.

Genetic endowments, determined before birth, represent a fundamental building block for individuals' accumulation of human capital and the formation of preferences. Unsurprisingly, studies of twins and adoptees reveal strong effects of genes on entrepreneurial entry. ${ }^{3}$ Comparing identical and fraternal twins, Nicolaou et al. (2008) and Zhang et al. (2009) find that half of the variation in entrepreneurship entry for women is due to genes, while Nicolaou and Shane (2010) estimate a similarly substantive heritability for both men and women's entrepreneurial entry and intentions. Focusing specifically on the nature and nurture components of parental entrepreneurship, Lindquist et al. (2015) compare adoptees with entrepreneurial and non-entrepreneurial parents and find a substantial role for pre-birth factors in explaining children's occupational choice. Overall, inherited genes - chronologically the first family influence - play a strong role in entrepreneurship. Siblings share on average $50 \%$ of their genetic material (Björklund et al., 2005), so the effects of genes on fundamental individual traits such as risk preferences, cognitive and non-cognitive ability create substantial similarity between children in the same family. We therefore expect that shared genes have a large (if not the largest) influence on sibling similarity in entrepreneurial behavior and are thus an important contributor to sibling correlations.

After birth, parents represent a steady and intensive source of investment and interaction, strongly shaping individuals' entrepreneurial human capital. Children quickly form expectations regarding occupations and role models, with exposure to parental entrepreneurship during early teens exerting a stronger influence on individual occupational choice than later exposure (Sørensen, 2007). Parental entrepreneurship may increase the salience or perceived attractiveness of entrepreneurship as a career path among offspring or provide them with general and specific business human capital (Parker, 2009). ${ }^{4}$ As a result, the literature has devoted substantial attention to these vital mechanisms and parental entrepreneurship is likely the strongest post-birth family determinant of sibling similarity in occupational choice.

During adolescence, children become progressively exposed to other environments outside the household, such as neighborhoods. Given regional differences in rates of entrepreneurship, parents' location decision may carry important implications. Giannetti and Simonov (2009) show that between-municipality variance in Sweden is almost ten times the within-municipality variance in entrepreneurship, and that a standard deviation increase in the proportion of entrepreneurs in the local labor market is associated with 25\% more entry into entrepreneurship. Pistaferri et al., 2020 find a positive effect of local firm density in individuals' province of residence at age 18 on entrepreneurial entry in Italy, but no contemporaneous, adulthood effect (neither do Michelacci and Silva, 2007). Entrepreneurial density also leads to the adoption of better management practices and higher entrepreneurial income, as predicted by learning models. Therefore, we expect that shared neighborhood influences in adolescence are an important contributor to sibling correlations in entrepreneurship, although their contribution is likely to be smaller than that of household role models due to both the timing of influences, as well as their intensity.

As individuals approach adulthood, parental resources - particularly their education and wealth - are likely to affect children's human and financial capital, with consequences for their entrepreneurship choices. Parental education serves as a proxy for the transfer of general human capital, whereas parental wealth may affect both children's educational achievement and their ability to rely on family for financing their venture. Indeed, studies find evidence consistent with capital constraints in entrepreneurship by documenting the importance of parental wealth for children's ventures (Holtz-Eakin et al., 1994a, 1994b; Blanchflower and Oswald, 1998). Together, parental education and wealth form the pool of resources children fall back on in their decision to become entrepreneurs, as well as their entrepreneurial performance. Due to the later timing of this influence, we expect it to be weaker than that of entrepreneurial parents. In Sections 2.1 and 2.2 we argue that its magnitude relative to neighborhood influences in explaining sibling correlations depends on type of entrepreneurship and child gender.

Beyond the factors outlined above, families provide a broader context for individual development, shaping values, psychological

\footnotetext{
${ }^{2}$ A key element of these new theories of human capital investments and human capital accumulation is the idea of dynamic complementarities, which means that investments are complementary across time. This implies that investments made early in life make future investments more productive or less costly. While related to the (chronological) life course perspective that Aldrich and Kim (2007) use when discussing potential determinants of occupational inheritance among children of the self-employed, our framework exhibits a clear and important difference from theirs. Most importantly, life course models allow for later life investments or opportunities to correct for a lack of investments (or opportunities) earlier in life. In our dynamic complementarity framework, the efficacy of investments made later in life hinges upon the current level of human capital that one possesses, which is (in turn) determined by the amount of investments made early on in life. Thus, investments made later in life may be too costly or ineffective to make up for a lack of investments (or opportunities) earlier in life.

${ }^{3}$ See, among others, Nicolaou et al. (2008); Nicolaou and Shane (2010); Zhang et al. (2009); Lindquist et al. (2015); Zunino (2016); Nicolaou et al. (2017).

${ }^{4}$ Business inheritance plays only a minor role (Parker, 2009): < 8\% of children become entrepreneurs in the same industry and year as their parents' exit in Denmark and Sweden (Sørensen, 2007; Dahl and Sorenson, 2012; Lindquist et al., 2015), while only between 1.6\% and 14\% of children take over their parents' company in the U.S. and Canada (Lentz and Laband, 1990; Aldrich et al., 1998; Fairlie and Robb, 2007a).
} 
traits, and preferences. These influences, while present throughout children's development, are likely to become relevant as individuals approach adulthood and make occupational choices. Several studies establish that parental immigration spurs entrepreneurship through the transmission of self-employment (which has a higher incidence among immigrant parents) and neighborhood choices (location in parishes with a higher share of self-employed immigrants), as well as potential labor market disadvantages for children with an immigrant background (Dunn and Holtz-Eakin, 2000; Edin et al., 2003; Andersson and Hammarstedt, 2010, 2011; Kerr and Mandorff, 2015). Whereas the first two influences are captured by parental and neighborhood role models, the latter should exert an influence on children's entrepreneurial behavior in adulthood. The late timing of these influences suggests that parents' immigration status explains only a small share of sibling similarity in entrepreneurship.

Similarly, family structure - captured by parents' marital status - may be associated with entrepreneurial values or outcomes. ${ }^{5}$ For example, children of single parents become more independent, while children of cohabiting parents benefit from household stability and cohesiveness. However, the relatively small share of families with alternative structures and the timing of this influence imply that family structure is unlikely to be a strong driver of sibling similarity.

Finally, siblings interact not only with parents, but also with each other, generating more similar entrepreneurial behavior. Peer effects in entrepreneurship have been convincingly identified within the workplace and universities (Nanda and Sørensen, 2010; Lerner and Malmendier, 2013; Kacperczyk, 2013) and sibling peer effects are observed in education (Joensen and Nielsen, 2018), crime (Eriksson et al., 2016), or substance use (Altonji et al., 2017). Sibling peers effects may also affect entrepreneurship, although these influences take place at a later stage, after individuals have had the chance to learn from role models inside and outside the household. Hence, we expect sibling peer effects to be a minor driver of sibling similarity.

The arguments above, drawing on human capital formation theories, suggest that the chronological order of family and community influences that shape entrepreneurship should be reflected in their relative importance for explaining sibling correlations. We thus expect that:

Hypothesis 2. Shared genes contribute the most to sibling correlations, followed by parental entrepreneurship, neighborhood effects and parental resources, and finally by parental immigration status, family structure, and sibling peers.

While examining the exact timing of family and community influences in entrepreneurship is beyond the scope of this study, our theoretical framework, summarized in Fig. 1, allows us to integrate a set of disparate findings in the entrepreneurship literature, thus painting a general picture of the relative importance of background determinants for entrepreneurship. Beyond their timing and intensity of exposure, family and community influences differ in the extent to which they affect the availability of learning opportunities or the availability of resources. We now turn to investigating two sources of heterogeneity which affect the importance of particular mechanisms, namely the type of entrepreneurship and gender.

\subsection{Unincorporated and incorporated firms}

As entrepreneurial firms exhibit great heterogeneity in antecedents, ambitions, and outcomes, scholars have criticized the conflation of different types of entrepreneurship under the umbrella of 'self-employment', questioning its use as a proxy for Schumpeterian entrepreneurship (Schoar, 2010; Henrekson and Sanandaji, 2014, 2019). To address this definitional concern, we consider the legal status of firms: whether a firm is incorporated or not (Levine and Rubinstein, 2017). On the one hand, incorporation offers limited liability, allowing entrepreneurs to pursue riskier investments in the search for greater rewards, and gives tax advantages beyond a certain income threshold (Parker, 2009). On the other hand, incorporation exposes entrepreneurs to increased regulatory oversight and additional capital requirements, creating constraints for some individuals (Levine and Rubinstein, 2018). Entrepreneurs thus incorporate their firm only when performance expectations exceed a certain threshold, such that the benefits of incorporation outweigh its costs, and higher-quality entrepreneurs are more likely to incorporate. Relative to unincorporated entrepreneurs, the incorporated are more educated, score higher on aptitude tests, and have more educated, wealthier parents (Tåg et al., 2016; Åstebro and Tåg, 2017; Humphries, 2017; Levine and Rubinstein, 2017, 2018). In our data, incorporated entrepreneurs have higher cognitive and non-cognitive ability, education, and lifetime incomes than unincorporated entrepreneurs, have more balanced skills, and enter more capital intensive industries, supporting the validity of this dichotomy.

Incorporated firms differ from unincorporated firms in their task content and outcomes. The latter require mostly routine manual tasks and are typically small, owner-operated firms with no employees and limited growth ambitions (Hurst and Pugsley, 2011). By contrast, incorporated firms require significant nonroutine cognitive and non-cognitive tasks (Levine and Rubinstein, 2017) and on average have more employees (Åstebro and Tåg, 2017), a higher likelihood of growth and reaching an IPO (Guzman and Stern, 2016), and higher entrepreneurial income (van Praag and Raknerud, 2014; Levine and Rubinstein, 2017; Humphries, 2017). Incorporated firms contribute to top income inequality, whereas unincorporated firms increase inequality at the bottom of the distribution (Halvarsson et al., 2018). Overall, both theoretical and empirical considerations stress the importance of distinguishing the unincorporated self-employed from the more growth-oriented, potentially transformative, incorporated entrepreneurs.

How does this distinction affect the relative importance of family and community influences in entrepreneurship? The human and financial capital requirements of incorporation imply that, relative to unincorporated entrepreneurship, families can influence children's occupational choices through a larger number of mechanisms, engendering additional sibling similarity. Moreover, the task

\footnotetext{
${ }^{5}$ See, for example, De Wit and Van Winden (1989); Dunn and Holtz-Eakin (2000); Hout and Rosen (2000); Halaby (2003); Hundley (2006); Tervo (2006); Edelman et al. (2016); Levine and Rubinstein (2017).
} 


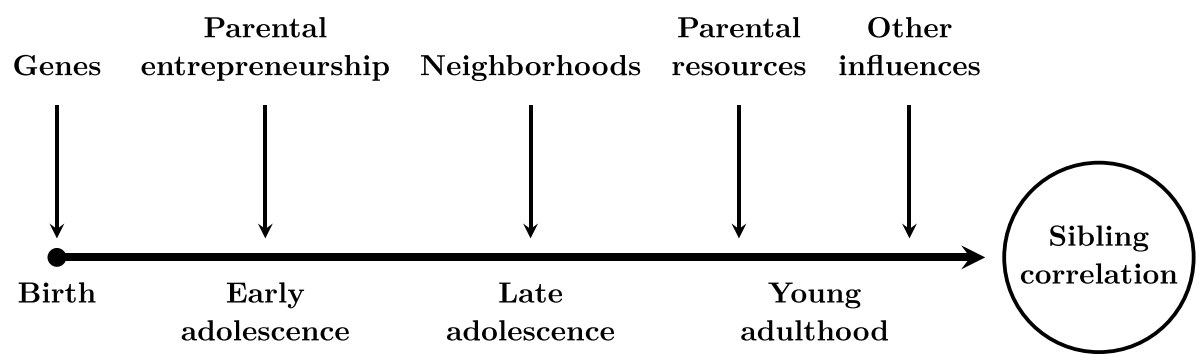

Fig. 1. Stylized model of the chronological sequence of exposure to family and community influences driving sibling correlations in entrepreneurship.

content in unincorporated firms is similar to the task content of paid employment, such that employees and unincorporated entrepreneurs may be more substitutable than employees and the incorporated. Consequently, children in the same family - whose ability and human capital greatly resemble each other's and are potentially suitable for unincorporated firms - should be found at similar rates in paid employment and as unincorporated entrepreneurs. In contrast, children whose abilities are suitable to incorporation should display larger concordance. Together, these arguments suggest that:

Hypothesis 3. Sibling correlations in incorporated entrepreneurship are larger than sibling correlations in unincorporated entrepreneurship.

Beyond role model availability, neighborhoods expose children to similar industrial structures and occupational concentrations. Indeed, certain professions are both concentrated geographically and more likely to be pursued through unincorporated firms. For instance, farms and different kinds of craftsmen in Sweden tend to operate as unincorporated firms and are often encountered in rural areas. ${ }^{6}$ As a result, children jointly exposed to such an industrial structure may be more likely to pursue similar professions, with similar legal status as entrepreneurs. In this case, occupational following (Aina and Nicoletti, 2018) explains the importance of neighborhoods as drivers of sibling similarity in entrepreneurship. As incorporated firms are less closely associated with a particular occupation, the industry structure effect of neighborhoods is likely to be particularly strong for unincorporated firms. ${ }^{7}$ Overall, we hypothesize that:

Hypothesis 4. Neighborhood effects contribute more to sibling correlations in unincorporated entrepreneurship than to sibling correlations in incorporated entrepreneurship.

Incorporated firms are subject to additional capital requirements, so individuals choosing to pursue this type of entrepreneurship require a larger pool of resources. Moreover, incorporated entrepreneurs' growth orientation and presence in more capital-intensive industries imply higher financial demands. Personal resources or access to finance then become particularly important, with potentially larger liquidity constraints for more able entrepreneurs (Evans and Jovanovic, 1989; Hurst and Lusardi, 2004; Levine and Rubinstein, 2018). With insufficient personal funds, children often obtain financial resources from family, and parental wealth has been shown to be an important driver of entrepreneurship entry and performance (Holtz-Eakin et al., 1994a, 1994b; Blanchflower and Oswald, 1998). Consequently, we expect that:

Hypothesis 5. Parental resources contribute more to sibling correlations in incorporated entrepreneurship than to sibling correlations in unincorporated entrepreneurship.

If shared genes play a large role in explaining sibling correlations, through which pathways do they affect children's entrepreneurship outcomes? Cognitive and non-cognitive skills have been shown to have a strong genetic component (Polderman et al., 2015; Grönqvist et al., 2017) and to matter for labor market outcomes (Lindqvist and Vestman, 2011) and entrepreneurship (Hartog et al., 2010; Levine and Rubinstein, 2017). As they are shared by siblings, cognitive and non-cognitive ability provide a pathway for explaining sibling similarity in entrepreneurship. In particular, the incorporated perform a broader set of non-cognitive, non-routine tasks, must manage a larger workforce and raise external finance, actions which require substantial social and leadership skills. Therefore, non-cognitive skills shared by siblings should have a stronger explanatory power for sibling correlations in this type of entrepreneurship:

Hypothesis 6. Non-cognitive ability contributes more to sibling correlations in incorporated entrepreneurship than to sibling correlations in unincorporated entrepreneurship.

\footnotetext{
${ }^{6}$ In our sibling sample, the recorded industry for unincorporated (incorporated) firms is agriculture in $12.5 \%(2.4 \%)$ of cases.

${ }^{7}$ Our argument mirrors that of Page and Solon (2003), who argue that much of the neighborhood correlation in earnings seen in the U.S. is due to the persistence with which urban born boys (and their brothers) tend to live and work in urban areas as adults. This geographical persistence means that urban boys tend to live in areas with similar economic structures, price levels, and wage levels as adults. Thus, part of the brother correlation, and much of the neighborhood correlation, is generated by this geographical persistence.
} 


\subsection{Gender differences}

Family and community influences may also generate different sibling correlations for men and women (Parker, 2009). The observed gender gap in entrepreneurship suggests that women may encounter barriers and possibly require additional human and financial capital to pass a higher entry threshold. At the same time, sons appear more likely than daughters to follow parents into entrepreneurship (Niittykangas and Tervo, 2005; Hundley, 2006; Schoon and Duckworth, 2012). Role models operate along gender lines, with men's (women's) propensity to become entrepreneurs strongly influenced by having entrepreneurial fathers (mothers) (Dunn and Holtz-Eakin, 2000; Hoffmann et al., 2015; Lindquist et al., 2015), but since fewer mothers are entrepreneurs, the impact of shared role models is weaker for women than for men. For similar reasons, sons are more likely to gain first-hand entrepreneurial experience working for their parents' business (Hoffmann et al., 2015). Our baseline proposition with regards to gender heterogeneity is therefore that:

Hypothesis 7. Brother correlations are larger than sister correlations in unincorporated and incorporated entrepreneurship.

We previously argued that the geographical concentration of occupations often pursued through unincorporated firms leads to stronger neighborhood effects in this type of entrepreneurship. Yet, these professions are often male dominated, as is the case in agriculture or construction work (see Online Appendix Figs. B.2 and B.3). The concentration of such occupations, coupled with the higher overall share of male entrepreneurs, implies that men have access to additional neighborhood role models and learning sources relevant for unincorporated firms. In other words, geographically concentrated, male-dominated professions produce genderspecific role models and occupational following (Bowen and Hisrich, 1986), so we expect that:

Hypothesis 8. Neighborhood effects contribute more to brother correlations than to sister correlations in unincorporated entrepreneurship.

The larger capital requirements of incorporation may also place different strains on men and women. That is, women encounter difficulties in accessing finance relative to men (Marlow and Patton, 2005; Alsos et al., 2006; Coleman and Robb, 2009; Sauer and Wilson, 2016), such that they are more likely to rely on parental resources for their entrepreneurial pursuits. Moreover, women are often found to be more risk averse then men (Robb and Watson, 2012) and may require a larger safety net in order to undertake a risky entrepreneurial endeavor. In this case, parental resources represent an insurance mechanism against the potential downside associated with new ventures. We therefore hypothesize:

Hypothesis 9. Parental resources contribute more to sister correlations than to brother correlations in incorporated entrepreneurship.

While we earlier hypothesized that sibling peer effects could play a role in explaining sibling correlations, brothers tend to interact more strongly with each other than sisters in competitive contexts (Conley, 2000; Joensen and Nielsen, 2018). Boys' more intense interaction and their desire to maintain achievement parity may lead to higher brother correlations in personal traits, such as risk-taking, ability, or education, and in labor market outcomes (Björklund and Jäntti, 2012; Schnitzlein, 2014; Eriksson et al., 2016). Brothers' interactions thus affect entrepreneurship - a stereotypically male, competitive occupation - both directly (i.e. if a male sibling becomes an entrepreneur, their brothers also pursue entrepreneurship due to competitive rivalry), as well as through higher similarity in other relevant traits, so we expect that:

Hypothesis 10. Sibling peer effects contribute more to brother correlations than to sister correlations in entrepreneurship.

Overall, our theoretical framework provides a clear expectation that i) background explains a substantial share of variation in entrepreneurship, ii) the relative importance of family and community influences broadly mirrors the chronological sequence of influences in individual development, and iii) these effects vary with type of entrepreneurship and gender. We now present the data and method used to empirically test these predictions.

\section{Data and method}

\subsection{Data}

We use a 70\% sample from Sweden's Multigenerational Register, which includes all persons born from 1932 onwards who have lived in Sweden at any time since 1961. All family ties are recorded in this register. We define siblings as those sharing the same biological or adoptive mother. Individuals in our sample can be matched to various official data sources using their unique personal identification numbers. Given the years for which entrepreneurship data is available (1993-2012), we restrict our sample to those born between 1960 and 1970, for whom we observe individual and parental occupational choices for a longer period. Thus, we follow the oldest cohort from age 33 to 52, and the youngest cohort from age 23 to 42 . Those who died or left Sweden before 1993 are dropped from the sample.

Consistent with the Swedish tax authorities, we define individuals as entrepreneurs when they derive the majority of their taxable labor income from an unincorporated or incorporated business they own in full or in part. For the years 1993-2012, we know if a person received the majority of their taxable labor income from an unincorporated or incorporated enterprise they own in part or in 
full (and possibly employing personnel). ${ }^{8}$ An incorporated business in our data is a privately owned, non-listed, limited liability stock company. $^{9}$

Our extensive margin measures of entrepreneurship, Unincorporated and Incorporated, are binary variables equal to 1 if the individual is ever categorized as the owner of an unincorporated and, respectively, incorporated firm, and zero otherwise. In any given year, no individual is classified as both Unincorporated and Incorporated. We use information on entrepreneurship and income between 1993 and 2012 to define our intensive margin outcomes. Specifically, we count the number of years individuals have been entrepreneurs, Years unincorporated and Years incorporated, as well as the income received while a business owner, Income unincorporated and Income incorporated. Our measure of income represents pre-tax total factor income, including earnings, taxable benefits (e.g. unemployment insurance, parental insurance, sick pay), and net capital gains (e.g. dividends, interest received or paid). We average entrepreneurial income across the years individuals were entrepreneurs and take the log of this average. Separating extensive and intensive margin outcomes allows us to distinguish individuals' willingness and ability to become entrepreneurs from the quality of their entrepreneurial effort.

We have also created a set of family-wide background variables to use in our accounting exercises aimed at quantifying the factors underlying sibling correlations. We define parental entrepreneurship in incorporated or unincorporated firms in the same way we do for children. We have information on parental education, immigrant status and income. Parental education records the highest degree completed in Sweden and is measured in seven different levels, from the old minimum, seven-year compulsory level, through to nineteen years for graduate school. Immigrant status takes a value of zero for parents born in Sweden and one otherwise. Parental income is defined as sum of maternal and paternal incomes, calculated as the log of the average of a parent's pre-tax total factor income for all available years from 1968 to 2012. This measure speaks directly to the availability of parental resources, as total factor income captures both labor earnings and returns on capital (financial wealth, rental property, and other rental assets) and is strongly correlated with wealth (Lefgren et al., 2012). In our empirical analysis, we introduce parental income as a set of dummy variables for deciles of the distribution, as well as dummies for the top $5 \%$ and top $1 \%$. These variables capture the skewed nature of the wealth distribution and are thus likely to be significant predictors of entrepreneurship choices (Hurst and Lusardi, 2004). Our family structure variable is based on information on parents' actual cohabitation when the child is 15 and contains six categories: both parents present, single mother, single father, mother with new husband, father with new wife, missing. Finally, we define neighborhoods using the most precise information available, namely on the parishes siblings live in at age 15.

For most male Swedish citizens in our sample we have military draft record data concerning height, weight, and body mass index around the age of 18. More importantly, for our analysis of pathways of genetic transmission, we use standardized test scores on a scale of 1 to 9 for logical, verbal, spatial, and technical skills (cognitive ability) and a measure of leadership skills (noncognitive ability) constructed from a structured interview with a psychologist, which was used to help select young men into officer training.

\subsection{Descriptive statistics}

Table 1 presents descriptive statistics for our sample of 696,231 individuals (356,847 men and 339,384 women) from 430,935 families. Panel A shows that $12.8 \%$ of individuals have been Unincorporated, while $8.4 \%$ have been Incorporated. The average number of Years unincorporated and Years incorporated are 5.9 and 5.8, respectively. Income unincorporated and Income incorporated are higher than permanent income (i.e. averaged over the years 1993-2012) and display larger variability (see Panel A in Table 2 for permanent income). As expected, income from incorporated firms is, on average, larger than income from unincorporated firms. Family variables are summarized in panel B. Most importantly, $15 \%$ of mothers and $24 \%$ of fathers have been unincorporated at least once, while $3.1 \%$ of mothers and $6.3 \%$ of fathers have been incorporated. Panel C shows that the average number of children is 2.8 per family, of which we capture 1.6 children per family on average in our sample. The majority of families consists of intact families. Finally, Panel D shows that our average parish, out of a total of 2650 parishes, comprises 259 individuals, while the largest includes 5286 individuals.

In Table 2, Panel A, we examine differences between entrepreneurs and employees. On average, the incorporated have higher education and lifetime incomes than employees, while the unincorporated have lower education and incomes. Unincorporated entrepreneurs tend to have lower cognitive and non-cognitive ability than employees, with the exception of technical ability, often associated with the manual labor performed by the self-employed (Levine and Rubinstein, 2017). By contrast, the incorporated have higher ability than the other groups, especially regarding leadership skills. The dispersion of these skills, measured by the intraindividual coefficient of variation (ratio of standard deviation to mean) of cognitive and noncognitive scores, is lower for incorporated entrepreneurs than for either of the other groups. Balanced skills thus appear to be a more common trait among the incorporated, and not all business owners, as previously thought (Lazear, 2005; Aldén et al., 2017). Incorporated firms are more

\footnotetext{
${ }^{8}$ Lindquist et al. (2015), Tåg et al. (2016), Åstebro and Tåg (2017), Humphries (2017), Halvarsson et al. (2018), and Vladasel (2018) distinguish between these types of business owners in Sweden using data similar to ours; Berglann et al. (2011), and van Praag and Raknerud (2014) do so in equivalent data from Norway.

${ }^{9}$ Data on unincorporated firm ownership, available from 1985 onwards, is used to compute parental unincorporated entrepreneurship. We only use data from 1993 onwards for children to make the results comparable to those for incorporation. In our data, $21.2 \%$ of unincorporated entrepreneurs have also been incorporated and $32.3 \%$ of incorporated entrepreneurs have also been unincorporated. $78.7 \%$ of the 18,867 individuals with both types of experience have first been unincorporated. This is consistent with a conceptual model where individuals first experiment with entrepreneurship on a smaller scale, learn about their potential entrepreneurial quality, and then decide whether to launch a growth-oriented, incorporated firm (Folta et al., 2010; Manso, 2016). While our paper focuses on the differences between firm types, we acknowledge that one type may also lead to the other.
} 
Table 1

Descriptive statistics.

\begin{tabular}{|c|c|c|c|c|c|}
\hline & Mean & S.D. & $N$ & Min & Max \\
\hline \multicolumn{6}{|l|}{ A. Business ownership outcomes } \\
\hline Unincorporated & 0.128 & $(0.334)$ & 696,231 & 0 & 1 \\
\hline Incorporated & 0.084 & $(0.277)$ & 696,231 & 0 & 1 \\
\hline Years unincorporated & 5.892 & $(5.238)$ & 89,061 & 1 & 20 \\
\hline Years incorporated & 5.785 & $(4.605)$ & 58,410 & 1 & 20 \\
\hline Unincorporated log income & 13.703 & $(1.202)$ & 89,061 & 0 & 19.7 \\
\hline Incorporated log income & 14.088 & $(0.969)$ & 58,410 & 9.1 & 19.1 \\
\hline \multicolumn{6}{|l|}{ B. Parental characteristics ${ }^{\mathrm{a}}$} \\
\hline Mother unincorporated & 0.148 & $(0.355)$ & 430,935 & 0 & 1 \\
\hline Father unincorporated & 0.243 & $(0.429)$ & 421,548 & 0 & 1 \\
\hline Mother incorporated & 0.031 & $(0.174)$ & 430,935 & 0 & 1 \\
\hline Father incorporated & 0.063 & $(0.244)$ & 421,548 & 0 & 1 \\
\hline Mother log income & 11.603 & $(0.828)$ & 429,550 & 0 & 17.1 \\
\hline Father log income & 12.174 & $(0.670)$ & 418,670 & 0 & 17.3 \\
\hline Mother years of schooling & 10.023 & $(2.787)$ & 423,737 & 7 & 19 \\
\hline Father years of schooling & 9.985 & $(3.012)$ & 406,914 & 7 & 19 \\
\hline Mother immigrant & 0.103 & $(0.304)$ & 430,935 & 0 & 1 \\
\hline Father immigrant & 0.086 & $(0.280)$ & 421,548 & 0 & 1 \\
\hline \multicolumn{6}{|l|}{ C. Demographics } \\
\hline Male & 0.513 & $(0.499)$ & 696,231 & 0 & 1 \\
\hline Twins & 0.021 & $(0.143)$ & 696,231 & 0 & 1 \\
\hline Adopted & 0.014 & $(0.119)$ & 696,231 & 0 & 1 \\
\hline Family size, total $^{\mathrm{a}}$ & 2.803 & $(1.306)$ & 430,935 & 1 & 18 \\
\hline Family size, in sample ${ }^{a}$ & 1.616 & $(0.767)$ & 430,935 & 1 & 8 \\
\hline \multicolumn{6}{|l|}{ Family structure at age $15^{\mathrm{a}}$} \\
\hline Both parents & $69.54 \%$ & & 299,657 & & \\
\hline Single mother & $18.69 \%$ & & 80,548 & & \\
\hline Single father & $3.74 \%$ & & 16,118 & & \\
\hline Mother with new husband & $4.98 \%$ & & 21,454 & & \\
\hline Father with new wife & $1.73 \%$ & & 7452 & & \\
\hline Missing & $1.32 \%$ & & 7506 & & \\
\hline \multicolumn{6}{|l|}{ D. Neighborhood characteristics } \\
\hline Parish size & 259.365 & $(475.779)$ & 2650 & 1 & 5286 \\
\hline Ever unincorporated & 0.162 & $(0.369)$ & 2650 & 0 & 1 \\
\hline Ever incorporated & 0.074 & $(0.262)$ & 2650 & 0 & 1 \\
\hline$\%$ Other parents unincorporated & 0.307 & $(0.138)$ & 2642 & 0 & 1 \\
\hline$\%$ Other parents incorporated & 0.043 & $(0.036)$ & 2642 & 0 & 0.5 \\
\hline
\end{tabular}

${ }^{a}$ Variables calculated at the family level to avoid over-weighting large families.

likely to be found in manufacturing of machinery, metal, electrical and optic tools, retail and wholesale trade, financial services, and computer and data services, whereas the Unincorporated are found more often in services and agriculture (Online Appendix Figs. B.1-B.3). These differences reflect different industries' financial requirements (Hurst and Lusardi, 2004), with incorporated entrepreneurs more likely to be encountered in capital intensive industries.

Panel B shows that employees and entrepreneurs also differ in their background. On average, the parents of the Incorporated have higher education and income than other parents. The unincorporated are more likely to have unincorporated (but not incorporated) parents than those in the other groups, whereas the incorporated are more than three times as likely to have incorporated parents relative to the other categories. Clearly, incorporated and unincorporated entrepreneurs differ in their observable characteristics and family backgrounds, including the type of entrepreneurial experiences they were exposed to as children. Moreover, these substantial differences are consistent with entrepreneurs and the self-employed being drawn from different parts of the ability distribution (Åstebro et al., 2011; Levine and Rubinstein, 2018).

\subsection{Method}

Sibling correlations are often used in labor economics (Björklund and Jäntti, 2011; Black and Devereux, 2011) and related variance decomposition techniques have been applied in management (McGahan and Porter, 1997; Mollick, 2012), estimating intraclass correlations (Certo et al., 2017). To calculate sibling correlations, we estimate family random effects models predicting individuals' decision to enter entrepreneurship at some point in their career, as well as the number of years they spend in entrepreneurship and their entrepreneurial income, conditional on entry. We exploit the fact that children are only observed in one family to obtain variance estimates for both family-level random effects and individual-level residuals, corresponding to the contributions of shared and, respectively, idiosyncratic influences. After controlling for cohort effects and gender (unless estimating separate models for men and women), we calculate sibling correlations as the ratio between the variance of the family-level random 
Table 2

Descriptive statistics by entrepreneurship status.

\begin{tabular}{|c|c|c|c|c|c|c|}
\hline & Employee & Unincorporated & Incorporated & $(2)-(1)$ & $(3)-(1)$ & $(3)-(2)$ \\
\hline & (1) & (2) & (3) & (4) & (5) & (6) \\
\hline \multicolumn{7}{|l|}{ A. Individual characteristics } \\
\hline Years of schooling & $\begin{array}{l}12.309 \\
(2.184)\end{array}$ & $\begin{array}{l}11.945 \\
(2.072)\end{array}$ & $\begin{array}{l}12.305 \\
(2.109)\end{array}$ & -0.364 & n.s. & 0.360 \\
\hline Log income & $\begin{array}{c}11.864 \\
(0.635)\end{array}$ & $\begin{array}{c}11.731 \\
(0.497)\end{array}$ & $\begin{array}{c}12.222 \\
(0.466)\end{array}$ & -0.133 & 0.357 & 0.491 \\
\hline Business income & & $\begin{array}{l}13.591 \\
(1.212)\end{array}$ & $\begin{array}{l}14.070 \\
(1.003)\end{array}$ & & & 0.479 \\
\hline Logical ability (men) & $\begin{array}{c}4.905 \\
(1.974)\end{array}$ & $\begin{array}{c}4.752 \\
(1.893)\end{array}$ & $\begin{array}{c}5.338 \\
(1.826)\end{array}$ & -0.152 & 0.433 & 0.585 \\
\hline Verbal ability (men) & $\begin{array}{c}4.797 \\
(1.774)\end{array}$ & $\begin{array}{c}4.672 \\
(1.735)\end{array}$ & $\begin{array}{c}5.076 \\
(1.633)\end{array}$ & -0.126 & 0.278 & 0.404 \\
\hline Spatial ability (men) & $\begin{array}{c}5.057 \\
(1.933)\end{array}$ & $\begin{array}{c}5.076 \\
(1.886)\end{array}$ & $\begin{array}{c}5.461 \\
(1.817)\end{array}$ & n.s. & 0.404 & 0.385 \\
\hline Technical ability (men) & $\begin{array}{c}4.897 \\
(1.897)\end{array}$ & $\begin{array}{c}4.932 \\
(1.814)\end{array}$ & $\begin{array}{c}5.356 \\
(1.767)\end{array}$ & 0.035 & 0.459 & 0.424 \\
\hline Leadership skills (men) & $\begin{array}{c}5.243 \\
(1.502)\end{array}$ & $\begin{array}{c}5.125 \\
(1.527)\end{array}$ & $\begin{array}{c}5.635 \\
(1.422)\end{array}$ & -0.118 & 0.392 & 0.510 \\
\hline Skill dispersion (men) & $\begin{array}{c}0.260 \\
(0.135)\end{array}$ & $\begin{array}{c}0.262 \\
(0.134)\end{array}$ & $\begin{array}{c}0.233 \\
(0.118)\end{array}$ & 0.002 & -0.027 & -0.029 \\
\hline \multicolumn{7}{|l|}{ B. Family characteristics } \\
\hline Mother unincorporated & $\begin{array}{l}0.137 \\
(0.344)\end{array}$ & $\begin{array}{l}0.230 \\
(0.421)\end{array}$ & $\begin{array}{l}0.202 \\
(0.402)\end{array}$ & 0.093 & 0.065 & -0.028 \\
\hline Father unincorporated & $\begin{array}{l}0.231 \\
(0.422)\end{array}$ & $\begin{array}{l}0.355 \\
(0.478)\end{array}$ & $\begin{array}{l}0.319 \\
(0.466)\end{array}$ & 0.123 & 0.088 & -0.035 \\
\hline Mother incorporated & $\begin{array}{l}0.024 \\
(0.154)\end{array}$ & $\begin{array}{l}0.032 \\
(0.177)\end{array}$ & $\begin{array}{l}0.120 \\
(0.325)\end{array}$ & 0.008 & 0.095 & 0.087 \\
\hline Father incorporated & $\begin{array}{l}0.053 \\
(0.224)\end{array}$ & $\begin{array}{l}0.065 \\
(0.246)\end{array}$ & $\begin{array}{l}0.195 \\
(0.396)\end{array}$ & 0.012 & 0.142 & 0.131 \\
\hline Mother log income & $\begin{array}{l}11.591 \\
(0.819)\end{array}$ & $\begin{array}{l}11.586 \\
(0.822)\end{array}$ & $\begin{array}{l}11.736 \\
(0.686)\end{array}$ & n.s. & 0.145 & 0.150 \\
\hline Father log income & $\begin{array}{l}12.166 \\
(0.649)\end{array}$ & $\begin{array}{l}12.126 \\
(0.722)\end{array}$ & $\begin{array}{l}12.355 \\
(0.635)\end{array}$ & -0.040 & 0.189 & 0.229 \\
\hline Mother schooling & $\begin{array}{l}9.996 \\
(2.785)\end{array}$ & $\begin{array}{l}10.141 \\
(2.842)\end{array}$ & $\begin{array}{l}10.372 \\
(2.859)\end{array}$ & 0.144 & 0.375 & 0.231 \\
\hline Father schooling & $\begin{array}{l}9.940 \\
(3.031)\end{array}$ & $\begin{array}{l}10.039 \\
(3.067)\end{array}$ & $\begin{array}{l}10.341 \\
(3.120)\end{array}$ & 0.099 & 0.400 & 0.301 \\
\hline Mother immigrant & $\begin{array}{l}0.110 \\
(0.312)\end{array}$ & $\begin{array}{l}0.120 \\
(0.325)\end{array}$ & $\begin{array}{l}0.087 \\
(0.282)\end{array}$ & 0.010 & -0.023 & -0.033 \\
\hline Father immigrant & $\begin{array}{l}0.091 \\
(0.288)\end{array}$ & $\begin{array}{l}0.101 \\
(0.301)\end{array}$ & $\begin{array}{l}0.075 \\
(0.263)\end{array}$ & 0.010 & -0.016 & -0.026 \\
\hline Intact family & $\begin{array}{l}0.705 \\
(0.456)\end{array}$ & $\begin{array}{l}0.700 \\
(0.458)\end{array}$ & $\begin{array}{l}0.772 \\
(0.420)\end{array}$ & -0.006 & 0.066 & 0.072 \\
\hline
\end{tabular}

Standard deviations in parentheses. All differences are significant at $1 \%$, except where noted (n.s.).

effects and the sum of the variance of family-level random effects and individual-level residuals (see Online Appendix A). Sibling correlations take values between 0 , i.e. shared influences do not matter, and 1, i.e. shared influences explain all the variation in entrepreneurship.

To disentangle the influences that drive the explanatory power of family background, we extend the sibling correlation framework in several ways. First, we estimate sibling correlations for twins, full, half, and adopted siblings, who differ in the extent to which they share their genetic architecture. Under a set of straightforward assumptions, including the traditional equal environment assumption, we can correlate an increase in the proportion of shared genes with changes in sibling correlations (Björklund et al., 2005). Sibling correlations thus allow us to compare the effects of nature and nurture and assess the contribution of shared genes to the explanatory power of family and community background in a novel way, without resorting to the classic twin or adoption study designs (Nicolaou et al., 2008; Lindquist et al., 2015).

Second, we decompose sibling correlations by controlling for observable parental characteristics common to all children in the same family and examining the relative decrease in sibling correlations. These traits absorb some of the family-level variation, reducing the variance of the random effects and, with it, the sibling correlation. This provides us with a metric for assessing the relative importance of mechanisms that include parental entrepreneurship, education, or income (Mazumder, 2008; Björklund et al., 2010). While potential correlations between parental characteristics limit our claims to causality, this 'accounting' exercise provides clear indications regarding shared factors that do or do not engender sibling similarity.

Third, by replacing family random effects with neighborhood random effects, we calculate neighborhood correlations - the extent 
Table 3

Sibling correlations in entrepreneurship.

\begin{tabular}{|c|c|c|c|c|c|}
\hline \multicolumn{2}{|l|}{ Entry } & \multicolumn{2}{|l|}{ Years } & \multicolumn{2}{|l|}{ Income } \\
\hline Unincorporated & Incorporated & Unincorporated & Incorporated & Unincorporated & Incorporporated \\
\hline
\end{tabular}

(1)

(2)

(3)

(4)

(5)

(6)

\begin{tabular}{|c|c|c|c|c|c|c|}
\hline \multicolumn{7}{|l|}{ A. All children } \\
\hline \multirow[t]{2}{*}{ Sibling correlation } & 0.212 & 0.341 & 0.214 & 0.386 & 0.209 & 0.346 \\
\hline & $(0.004)$ & $(0.006)$ & (0.009) & $(0.009)$ & $(0.010)$ & (0.011) \\
\hline Individuals & 696,231 & 696,231 & 89,061 & 58,410 & 89,061 & 58,410 \\
\hline Families & 430,935 & 430,935 & 80,551 & 53,157 & 80,551 & 53,157 \\
\hline \multicolumn{7}{|l|}{ B. Brothers } \\
\hline \multirow[t]{2}{*}{ Brother correlation } & 0.292 & 0.404 & 0.310 & 0.447 & 0.296 & 0.416 \\
\hline & $(0.007)$ & (0.007) & (0.013) & $(0.011)$ & $(0.014)$ & $(0.013)$ \\
\hline Individuals & 356,847 & 356,847 & 55,606 & 42,650 & 55,606 & 42,650 \\
\hline Families & 278,107 & 278,107 & 51,731 & 39,592 & 51,731 & 39,592 \\
\hline \multicolumn{7}{|l|}{ C. Sisters } \\
\hline \multirow[t]{2}{*}{ Sister correlation } & 0.213 & 0.351 & 0.169 & 0.381 & 0.158 & 0.360 \\
\hline & $(0.010)$ & (0.013) & $(0.026)$ & (0.029) & $(0.026)$ & (0.033) \\
\hline Individuals & 339,384 & 339,384 & 33,455 & 15,760 & 33,455 & 15,760 \\
\hline Families & 267,894 & 267,894 & 31,155 & 15,274 & 32,155 & 15,274 \\
\hline
\end{tabular}

Standard errors in parentheses. We estimate maximum likelihood random effects logistic models in columns (1) and (2) and restricted maximum likelihood random effects models in columns (3)-(6).

to which children in the same parish at age 15 are similar in their entrepreneurial behavior. To address family sorting across neighborhoods, we control for parental characteristics in these models. We then assess the relative importance of communities and families for entrepreneurship by comparing neighborhood and sibling correlations.

Finally, by comparing sibling correlations across children of different birth spacings, we assess how interaction strength - assumed to decrease with spacing - affects sibling similarity (Eriksson et al., 2016). To more directly get at sibling peer effects, we also use a correlated random effects model (Altonji et al., 2017), allowing us to translate the effect of a sibling's entrepreneurship entry at $t-1$ on the other sibling's entrepreneurship entry at time $t$ into a peer effects estimate that maps onto the sibling correlation. Overall, sibling correlations offer a parsimonious, yet flexible, approach to quantifying the total importance of family and community background for entrepreneurship, as well as the relative importance of specific influences. A more detailed description of the different empirical models is available in Online Appendix A.

\section{Sibling correlations in entrepreneurship}

We report sibling correlations in entrepreneurship in Table 3. Column (1) shows sibling correlations for Unincorporated, our extensive margin measure for ever being an unincorporated entrepreneur. In Panel A, the overall sibling correlation is 0.21: that is, $21 \%$ of the total variation in Unincorporated is determined by family background and community influences. We then split our sample between men ('brothers') and women ('sisters'). For brothers, the sibling correlation in Unincorporated is 0.29 (panel B), whereas for sisters it is 0.21 (panel C). In column (2), the overall sibling correlation for ever being an incorporated entrepreneur, Incorporated, is 0.34. The correlation is 0.40 for brothers and 0.35 for sisters.

Sibling correlations for our intensive margin outcomes, Years unincorporated and Years incorporated, are reported in columns (3) and (4) of Table 3. The overall correlations are 0.21 and 0.39 (panel A), respectively, and similar to our extensive margin results. For brothers, family and community background are responsible for $31 \%$ and $45 \%$ of the variation in persistence in unincorporated or incorporated firm ownership (panel B). The equivalent numbers for sisters are 17\% and 38\% (panel C). In columns (5) and (6), we report sibling correlations in income earned from entrepreneurship, Income unincorporated and Income incorporated. Brother correlations are 0.30 and 0.42 for unincorporated and incorporated income (panel B), respectively, and sister correlations are 0.16 and 0.36 (panel C).

To get a broader view of the importance of families for entrepreneurial persistence, we create a set of dummies for individuals being entrepreneurs for more than $x$ years, where $x=1,2, \ldots, 10$. Fig. 2 plots sibling correlations in these outcomes. Incorporated correlations are higher than Unincorporated ones, and brother correlations are higher than sister correlations, especially for unincorporated firms. We also observe a positive relationship between years of entrepreneurship and the influence of background. At the median number of years unincorporated (4 years), correlations are 0.36 for brothers and 0.26 for sisters; at the median number of years incorporated ( 5 years), they are 0.48 for brothers and 0.46 for sisters. Correlations further increase for being an entrepreneur for up to 10 years, reaching 0.72 for incorporated brothers.

The estimated sibling correlations suggest that family background and community influences are important determinants of entrepreneurship. Background explains between $30 \%$ and $45 \%$ of the variation in entry, persistence, and income for men and 


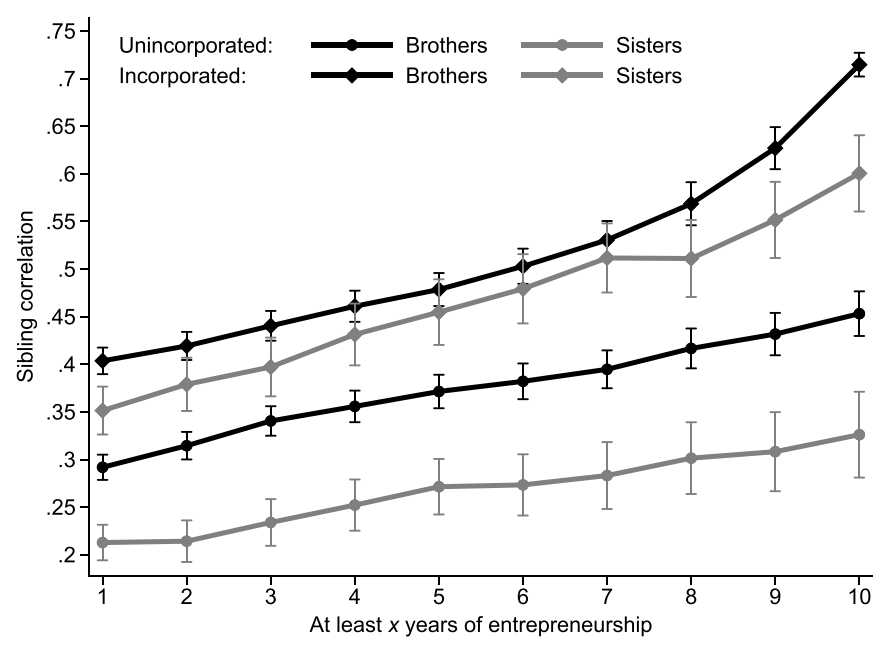

Fig. 2. Sibling correlations in being a business owner for at least $x$ years, separately by gender and type of business, with $95 \%$ confidence intervals.

between 16\% and 38\% for women. These number exceed correlations for education and earnings (Björklund and Jäntti, 2012), as well as for men's ability (Section 4.6). Our findings confirm hypothesis 1: family and community are indeed salient determinants of entrepreneurship. Moreover, as predicted by hypotheses 3 and 7, family and community background are more important for becoming Incorporated than for becoming Unincorporated, as well as for brothers relative to sisters. ${ }^{10}$

We now turn towards exploring the relative importance of background influences, summarized in Fig. 3. Given how similar sibling correlations at the extensive and intensive margins are, we focus on entrepreneurship entry outcomes throughout the paper and highlight differences between the extensive and intensive margin results when they arise.

\subsection{Shared genes}

Fig. 4 displays correlations for our pairs of twin, full, half, and adopted siblings, separately for brothers (left panels) and sisters (right panels), as well as for unincorporated (top panels) and incorporated (bottom panels) entrepreneurship. Across all panels, an increase in the fraction of shared genes between siblings is associated with a higher correlation. In the estimator proposed by Björklund et al. (2005), the slope of this relationship provides the percentage of the sibling correlation that is due to shared genes. Despite being based on a number of strong, simplifying assumptions, the model fits the data quite well, producing estimates of the sibling correlations very close to the ones we observe in our data (Online Appendix Table B.4). As we show in Fig. 3, 47\% of the brother correlation in being Unincorporated is explained by shared genes, while the equivalent number for being Incorporated is $48 \%$. The contribution of shared genes to sister correlations in being Unincorporated or Incorporated is somewhat larger, at $72 \%$ and, respectively, 58\%, although standard errors are also higher. In line with more traditional twin studies (Nicolaou and Shane, 2010; Zunino, 2016), our results based on correlations for different siblings types suggest that shared genes explain roughly half of the total influence of family and community background in entrepreneurship, with slightly higher values for women. Thus, shared genes represent both the earliest influence shared by siblings and a strong determinant of sibling similarity in entrepreneurship, providing initial support for hypothesis 2 .

\subsection{Parental entrepreneurship}

The next step in decomposing sibling correlations into their constitutive background influences is to assess the importance of parental entrepreneurship. We re-estimate brother and sister correlations controlling for maternal and paternal unincorporated and incorporated entrepreneurship, taking the associated decrease in sibling correlations as a measure of the importance of this

\footnotetext{
${ }^{10}$ Sibling correlations are robust to different subsamples and outcome definitions (Online Appendix Table B.2). These include: (1) excluding singletons, (2) using data from 1985 onwards for unincorporated outcomes, (3) using data only on individual careers between ages 25 and 40 , (4) defining the family through the father, (5) excluding families with an adoptive father, (6) excluding families with an adoptive mother, (7) restricting the sample to non-twin pairs, (8) restricting the sample to closely spaced non-twin pairs (born 12 to 24 months apart), (9) restricting the sample to families captured in their entirety, (10) families for which data on parental characteristics is complete, (11) including individual and parental birth year dummies, (12) excluding families with parents older than 65 in 1993, (13) excluding families with parents older than 65 or who left the sample before 1993, (14) excluding families where parents were farmers, and (15) a falsification test whereby we replicate the original cluster structure of our data and randomly assign individuals to these clusters (to show that sibling correlations pick up more than statistical noise). The correlations for male-only sibships are larger than for female-only sibships across all outcomes, while mixed-gender correlations are usually the lowest (Online Appendix Table B.3).
} 


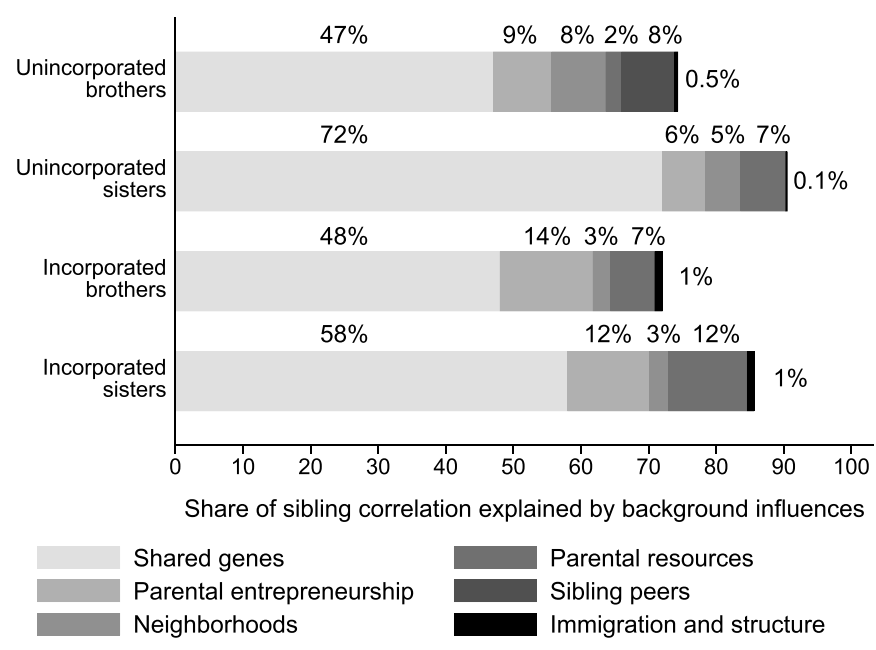

Fig. 3. Share of sibling correlations explained by individual family and community influences (rounded to the nearest integer when larger than $1 \%$ ).

influence. ${ }^{11}$ The results, summarized in Fig. 3, show that parental entrepreneurship explains $8.7 \%$ of the brother correlation and $6.4 \%$ of the sister correlation in being Unincorporated. These numbers are higher for being Incorporated, $13.8 \%$ for brothers and $12.2 \%$ for sisters.

The coefficients on parental entrepreneurship (Online Appendix Table B.5) show that paternal (maternal) entrepreneurship is particularly important for brothers (sisters), in line with the gender role-model conjecture (Dunn and Holtz-Eakin, 2000; Lindquist et al., 2015; Hoffmann et al., 2015). Parental role models are also type-specific, as unincorporated (incorporated) parents have a stronger effect on being Unincorporated (Incorporated). At the intensive margin, the contribution of parental entrepreneurship to sibling correlations is slightly smaller (Online Appendix Table B.7), suggesting that parental entrepreneurship matters mainly for sibling similarity in entrepreneurship entry, rather than in subsequent performance, providing further evidence for parents as role models in occupational choice.

\subsection{Neighborhoods}

To understand the role of neighborhoods, we estimate correlations using the parish of residence at age 15 as a cluster and controlling for observable parental characteristics to address family selection into neighborhoods. ${ }^{12}$ As Fig. 3 shows, neighborhoods contribute $8 \%$ to brother correlations and $5.2 \%$ to sister correlations in being Unincorporated. The equivalent numbers are $2.6 \%$ and $2.8 \%$ for Incorporated brothers and sisters, respectively. The intensive margin results are similar, with one exception: brothers' neighborhood correlation in Years unincorporated accounts for over 18\% of the brother correlation in Years unincorporated. This exception is consistent with our industry structure argument, as male-dominated professions in sectors such as agriculture or construction have longer tenures due to occupation-specific human capital.

The key takeaway is that neighborhoods can only explain a small fraction of sibling correlations, usually $<8 \%$ of sibling correlations. In line with our proposed hierarchy of influences, neighborhoods contribute less to sibling correlations than parental entrepreneurship. However, as predicted by hypotheses 4 and 8, neighborhoods appear particularly important for unincorporated firms and explain most of the observed gender difference in sibling correlations among unincorporated entrepreneurs. Controlling for the share of entrepreneurial parents in the parish, we find that exposure to a dense entrepreneurial environment in adolescence explains roughly a third of neighborhood correlations. Notably, the share of incorporated parents strongly affects both brothers' and sisters' incorporation choices. These results provide direct evidence for the existence of a local entrepreneurial spirit and/or role modeling effect on entrepreneurship (Giannetti and Simonov, 2009; Pistaferri et al., 2020). Yet, they leave room for our second hypothesized mechanism - regional differences in the prevalence of male-dominated occupations - to contribute to neighborhood effects, especially for brothers.

\footnotetext{
${ }^{11}$ See Online Appendix Table B.5 for full results. We show that our accounting exercise picks up true variation in parental entrepreneurship (compared to mechanical decreases produced by controlling for more variables) by computing the explanatory power of a set of random variables in Online Appendix Table B.6, which hovers around 0\%. Online Appendix Table B.7 shows the results for all siblings, brothers, and sisters, for both extensive and intensive margin outcomes.

${ }^{12}$ Neighborhood correlations and their contribution to sibling correlations are reported in Online Appendix Table B.8. Neighborhood correlations for all siblings, brothers, and sisters, at both the extensive and intensive margins are reported in Online Appendix Table B.9.
} 

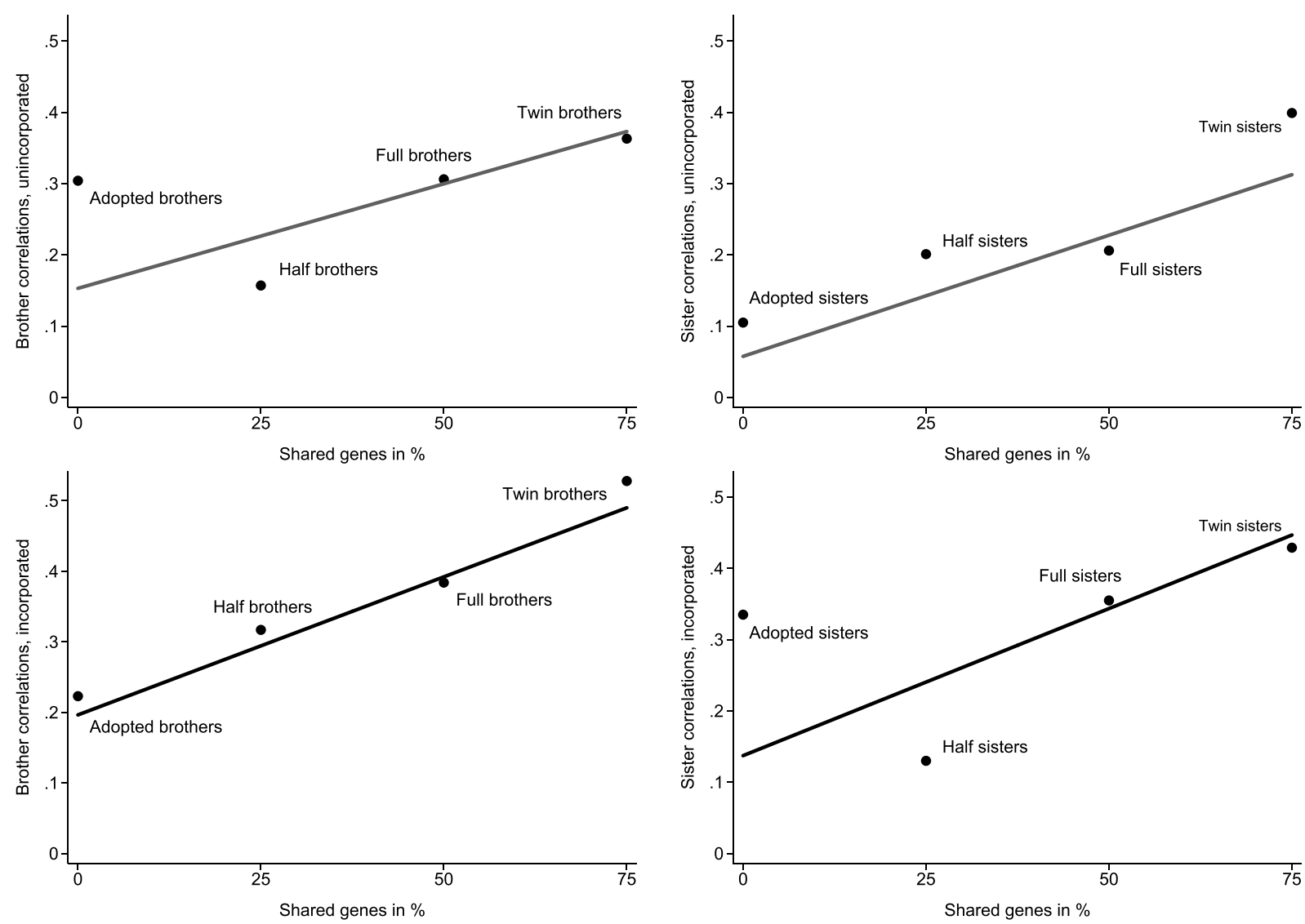

Fig. 4. Twin, full, half, and adopted sibling correlations in entrepreneurship (with linear fit).

\subsection{Parental resources}

Returning to our accounting exercise, we compute sibling correlations controlling for parental education (with education level dummies) and total factor income (a proxy for parental wealth, included as dummies for deciles, top 5\% and top $1 \%$ of the distribution). Fig. 3 shows that parental resources explain $2.3 \%$ of the brother correlation and $6.8 \%$ of the sister correlation in being Unincorporated. The equivalent numbers are $6.5 \%$ and $11.7 \%$ for brothers and sisters being Incorporated, respectively. These results confirm hypothesis 5 - that parental resources matter more for incorporation - and hypothesis 9 - that they matter more for women. That is, a woman whose parents are in the top decile of parental income has 3-7.2 times higher odds of becoming incorporated compared to a woman whose parents are in the bottom decile. Parental education and income have a stronger explanatory power at the intensive margin, especially for entrepreneurial income (Online Appendix Table B.7), suggesting that parental resources affect not only entry, but, perhaps more importantly, entrepreneurial performance.

\subsection{Sibling peer effects, parental immigration, and family structure}

We first examine sibling correlations at different birth spacings based on month of birth data, from twins (zero spacing), through siblings born at least 12 months apart in rolling intervals of 12 months, and to sibling spacings of 108 months. Results for unincorporated and incorporated entrepreneurship in Fig. 5 suggest that for non-twins there is no obvious relationship with birth spacing, a pattern common across outcomes and gender (Online Appendix Fig. B.4). More formally, we apply a correlated random effects approach (Altonji et al., 2017) to study the effect of a sibling's entrepreneurship at time $t-1$ on the other sibling's entrepreneurship at time $t$ (full results available in Online Appendix Tables B.10-B.15). Sibling peer effects are positive and significant only for unincorporated brothers. This effect explains around 7.2-7.8\% of the brother correlation in being Unincorporated, as shown in the top horizontal bar in Fig. 3. Overall, sibling peer effects are not particularly important in entrepreneurship, with the exception of unincorporated brothers, as partly predicted by hypothesis 10 .

Parental immigration and family structure contribute little to sibling correlations, as shown in Fig. 3: together, they explain at most 1\% (see also Panel D of Online Appendix Table B.5). The associated odds ratios suggest a concentration of immigrant entrepreneurship in unincorporated self-employment and that parental cohabitation reduces the odds of being Unincorporated while it increases those of being Incorporated, in line with Levine and Rubinstein (2017). 
Unincorporated

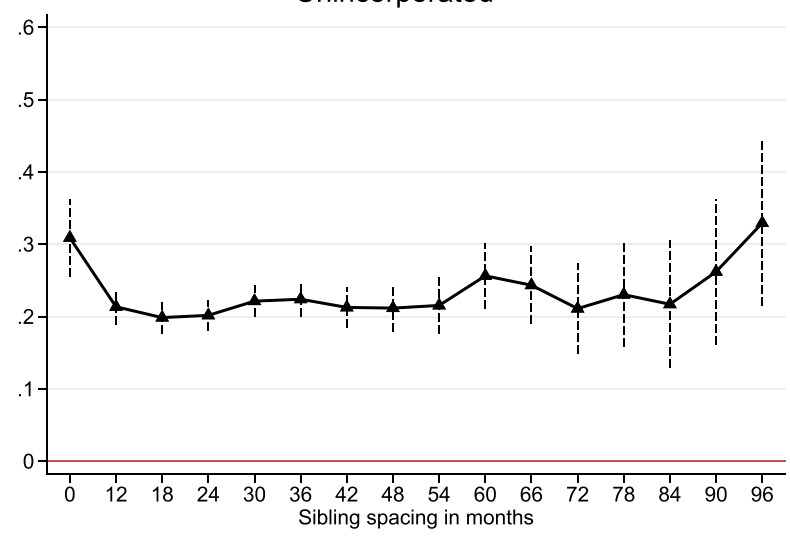

Incorporated

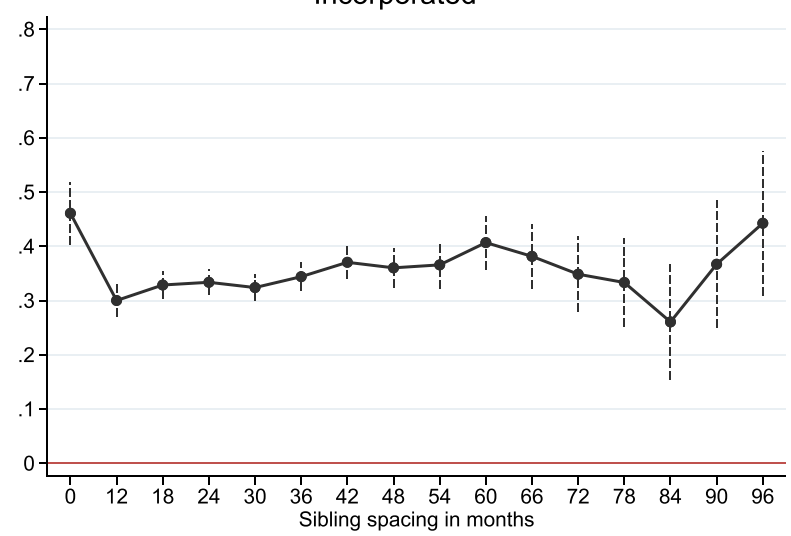

Fig. 5. Sibling correlations in entrepreneurship by spacing, with $95 \%$ confidence intervals.

\subsection{Cognitive and non-cognitive ability}

Panel A of Table 4 reports brother correlations in the variables obtained from military data. Brother correlations in height, weight and BMI at age 18 are 53\%, 43\%, and 40\%, respectively, while those in (non)cognitive test scores range from $25 \%$ for technical ability to $32 \%$ for leadership. Brother correlations in entrepreneurship for this sample, reported in columns (9)-(14) of Panel B, range

Table 4

Accounting for cognitive and noncognitive characteristics.

\begin{tabular}{|c|c|c|c|c|c|c|c|}
\hline $\begin{array}{l}\text { Height } \\
\text { (1) }\end{array}$ & $\begin{array}{l}\text { Weight } \\
\text { (2) }\end{array}$ & $\begin{array}{l}\text { BMI } \\
\text { (3) }\end{array}$ & $\begin{array}{l}\text { Logical } \\
\text { (4) }\end{array}$ & $\begin{array}{l}\text { Verbal } \\
(5)\end{array}$ & $\begin{array}{l}\text { Spatial } \\
\text { (6) }\end{array}$ & $\begin{array}{l}\text { Technical } \\
\text { (7) }\end{array}$ & $\begin{array}{l}\text { Leadership } \\
\text { (8) }\end{array}$ \\
\hline \multicolumn{8}{|c|}{ A. Sibling correlations in given outcomes } \\
\hline \multirow[t]{3}{*}{$\begin{array}{c}0.533 \\
(0.005)\end{array}$} & $\begin{array}{c}0.428 \\
(0.006)\end{array}$ & $\begin{array}{c}0.400 \\
(0.006)\end{array}$ & $\begin{array}{c}0.290 \\
(0.006)\end{array}$ & $\begin{array}{c}0.298 \\
(0.006)\end{array}$ & $\begin{array}{c}0.261 \\
(0.006)\end{array}$ & $\begin{array}{c}0.248 \\
(0.006)\end{array}$ & $\begin{array}{c}0.315 \\
(0.006)\end{array}$ \\
\hline & & \multicolumn{2}{|c|}{ Entry } & \multicolumn{2}{|c|}{ Years } & \multicolumn{2}{|c|}{ Income } \\
\hline & & $\begin{array}{l}\text { Uninc. } \\
\text { (9) }\end{array}$ & $\begin{array}{l}\text { Inc. } \\
\text { (10) }\end{array}$ & $\begin{array}{l}\text { Uninc. } \\
\text { (11) }\end{array}$ & $\begin{array}{l}\text { Inc. } \\
\text { (12) }\end{array}$ & $\begin{array}{l}\text { Uninc. } \\
\text { (13) }\end{array}$ & $\begin{array}{l}\text { Inc. } \\
\text { (14) }\end{array}$ \\
\hline \multicolumn{8}{|c|}{ B. Sibling correlations in entrepreneurship, no controls } \\
\hline & & 0.246 & 0.347 & 0.301 & 0.428 & 0.277 & 0.416 \\
\hline & & $(0.014)$ & $(0.014)$ & $(0.027)$ & $(0.021)$ & $(0.029)$ & $(0.023)$ \\
\hline \multicolumn{8}{|c|}{ C. Sibling correlations in entrepreneurship, with controls } \\
\hline & & 0.242 & 0.337 & 0.287 & 0.415 & 0.256 & 0.383 \\
\hline & & $(0.014)$ & $(0.014)$ & $(0.027)$ & $(0.022)$ & $(0.029)$ & 0.383 \\
\hline & & $1.55 \%$ & $2.72 \%$ & $4.41 \%$ & $2.94 \%$ & $7.57 \%$ & $7.97 \%$ \\
\hline & & \multicolumn{2}{|c|}{ Odds ratios: } & & \multicolumn{2}{|c|}{ Coefficients: } & \\
\hline Height & & $0.997^{* *}$ & $1.044^{* *}$ & 0.006 & $0.020^{* *}$ & $0.003^{*}$ & $0.008^{* *}$ \\
\hline Weight & & $1.005^{* *}$ & 1.000 & 0.002 & $0.011^{* *}$ & $-0.002^{* *}$ & $-0.004^{* *}$ \\
\hline Logical & & $0.919^{* *}$ & 0.995 & $-0.145^{* *}$ & $-0.084^{* *}$ & $0.061^{* *}$ & $0.053^{* *}$ \\
\hline Verbal & & $0.942^{* *}$ & 0.905 & $-0.235^{* *}$ & $-0.189^{* *}$ & $0.039^{* *}$ & $0.065^{* *}$ \\
\hline Spatial & & $1.027^{* *}$ & 1.006 & $-0.020^{* *}$ & -0.001 & -0.003 & $-0.004^{* *}$ \\
\hline Technical & & $1.031^{* *}$ & $1.045^{* *}$ & $0.038^{* *}$ & 0.021 & $0.015^{* *}$ & 0.003 \\
\hline \multirow[t]{8}{*}{ Leadership score: } & 2 & $1.263^{* *}$ & $1.494^{* * *}$ & $0.257^{* *}$ & -0.108 & $0.126^{* *}$ & 0.099 \\
\hline & 3 & 1.111 & $1.700^{* *}$ & $0.755^{* *}$ & 0.657 & 0.098 & 0.023 \\
\hline & 4 & $1.040^{* *}$ & $2.138^{* *}$ & $1.244^{* *}$ & $1.092^{* *}$ & $0.117^{* *}$ & -0.037 \\
\hline & 5 & 1.024 & $2.805^{* *}$ & $1.212^{* *}$ & $1.212^{* *}$ & $0.194^{* *}$ & $0.057^{* *}$ \\
\hline & 6 & 1.023 & $3.213^{* *}$ & $0.613^{*}$ & 0.725 & $0.357^{* *}$ & $0.181^{* *}$ \\
\hline & 7 & 1.025 & $4.152^{* *}$ & 0.413 & 0.453 & $0.459 * *$ & $0.300^{* *}$ \\
\hline & 8 & $1.092^{* *}$ & $4.412^{* *}$ & -0.108 & $0.247^{* *}$ & $0.653^{* *}$ & $0.410^{* *}$ \\
\hline & 9 & $1.313^{* *}$ & $5.818^{* * *}$ & $-0.530^{* *}$ & 0.183 & $0.761^{* *}$ & $0.430^{* *}$ \\
\hline
\end{tabular}

\footnotetext{
$* * * p<0.01$ not reported for brevity. Standard errors in parentheses. Percentages in Panel C indicate the contribution of cognitive and noncognitive skills to the sibling correlations in Panel B. BMI is highly correlated with weight $(\rho \approx 0.87)$ and is excluded in Panel C. Leadership dummies are jointly significant, with $p<0.001$. At the extensive margin, the sample comprises 164,390 men in 144,306 families. At the intensive margin, there are 25,370 men in 24,518 families for unincorporated outcomes, and 22,601 men in 21,709 families for incorporated outcomes.

*** $p<0.05$.

${ }^{*} p<0.1$
} 
between $25 \%$ and $43 \%$, similar to their counterparts from Table 3, but higher than those in (non)cognitive skills. We then add these controls to our models in Panel C. Test scores are significant predictors of entrepreneurship entry in columns (9) and (10), explaining $3.9 \%$ and $1.8 \%$ of the correlations in becoming Unincorporated and Incorporated, respectively. The odds ratios are all close to 1 , and both entrepreneur types have slightly lower verbal and logical scores and slightly higher spatial and technical abilities. In columns (11)-(14), cognitive ability is associated with lower persistence, but higher business income, especially for logical and verbal ability (and technical ability in the case of unincorporated entrepreneurship).

The odds ratios and coefficients on leadership skills provide a more nuanced story. Scoring well on this test is not correlated with becoming Unincorporated. In stark contrast, and in line with hypothesis 6, leadership skills are strong predictors of becoming Incorporated: scores above the median raise the propensity to become Incorporated by a factor of 3 to 5 . These skills are also highly correlated across brothers (32\%), which implies that they depend in part on a shared family origin and help us understand why the sibling correlation in Incorporated is greater than the sibling correlation in Unincorporated. Furthermore, above median leadership skills are positively associated with business income (Hartog et al., 2010). Together, cognitive and non-cognitive ability explain $8 \%$ of sibling correlations in entrepreneurial income.

\section{Discussion}

Despite the common claim that 'entrepreneurship runs in the family', we still lack an understanding of the total importance of families and communities, as well as the relative importance of different background factors in entrepreneurship (Parker, 2009). In this paper, we draw on human capital accumulation theories (Cunha and Heckman, 2007, 2008; Cunha et al., 2010) to argue for a hierarchy of family and community influences in entrepreneurship based on the timing of these influences in individuals' lives. In a similar vein to Aldrich and Kim (2007), we hypothesize that earlier influences shape individuals' entrepreneurship entry, persistence, and income more strongly than later ones. Our theoretical framework suggests a three-tier hierarchy, with a large role played by shared genes, followed by early influences such as parental entrepreneurship, neighborhoods, and parental resources, and by later influences such as sibling peers, parental immigration, and family structure. We thus propose that the total influence of families goes far beyond that implied by a narrow focus on parental entrepreneurship, which has been the center of much research (Blanchflower and Oswald, 1998; Sørensen, 2007; Laspita et al., 2012; Lindquist et al., 2015). We also argue that some influences are stronger for incorporated relative to unincorporated entrepreneurship, reflecting the human and financial capital intensive nature of incorporation (Levine and Rubinstein, 2017, 2018). The posited hierarchy of family and community influences displays gender heterogeneity, as men and women respond differently to contextual stimuli and face distinct obstacles to entry and performance.

To provide empirical evidence for our hypotheses, we introduce sibling correlations as a novel methodological tool to the study of entrepreneurship. By assessing the similarity of siblings' entrepreneurial outcomes, we obtain an estimate of the contribution of shared family and community background to the variation of entrepreneurial outcomes. In our sample of Swedish individuals, family and community background explain between $16 \%$ and $45 \%$ of variation in entrepreneurship entry, persistence, and income. These numbers are often larger than those obtained for other outcomes in Sweden, including earnings, education, cognitive and noncognitive ability (Björklund and Jäntti, 2012) and match our expectation that families and communities are important determinants of entrepreneurship. We also find evidence for our proposed hierarchy of influences, with shared genes explaining about half of sibling correlations. Parental entrepreneurship, neighborhoods, and parental resources each explain between $2 \%$ and $14 \%$ of sibling correlations, whereas parental immigration, family structure, and sibling peers usually explain $<1 \%$. Sibling correlations in incorporation (34\%-45\%) are higher than those in unincorporated entrepreneurship (16\%-31\%), and reflect the larger predicted contributions of parental incorporation and resources to this more growth-oriented venture type. Sibling correlations for men $(29 \%-45 \%)$ are higher than those for women (16\%-38\%), with sibling peers and neighborhoods as strong drivers of men's unincorporated entrepreneurship, and parental resources as an important determinant of women's incorporation. Finally, men's leadership skills strongly predict becoming incorporated and have a positive impact on entrepreneurial income, explaining about $8 \%$ of brother correlations.

\subsection{Theoretical implications}

Our sibling correlation results provide novel evidence that entrepreneurship does, indeed, run in the family. Siblings' shared background explains up to $45 \%$ of the variation in entrepreneurship, highlighting the particular salience of the family and community context - the earliest encountered by individuals - for becoming and performing as an entrepreneur. This result emphasizes the role of early influences in entrepreneurship and provides an explanation for two stylized facts in the literature. First, while the influence of later organizational contexts has been acknowledged, their effect stems largely from entrepreneurial predisposition, or the selection of individuals into a particular environment, rather than the treatment effect of that environment (Özcan and Reichstein, 2009; Elfenbein et al., 2010; Roach and Sauermann, 2015; Tåg et al., 2016). Our results concerning the primacy of earlier influences thus provide a theoretical explanation for why later influences have a smaller contribution to entrepreneurial outcomes. Second, entrepreneurship education programs have been shown to positively affect individuals' entrepreneurial intentions, skills, or entry when they are in primary school and high school (Huber et al., 2014; Elert et al., 2015), but not when they are in university (Oosterbeek et al., 2010; von Graevenitz et al., 2010) or active in the labor market (Fairlie et al., 2015). Since the bulk of family influences affect the formation of entrepreneurial skills and preferences at a young age, it is not surprising that entrepreneurship education programs become progressively ineffective as individuals enter into adulthood. As a result, our theoretical framework provides a useful lens for future investigations of the relative importance of entrepreneurial determinants, both inside and outside the family. 
Regarding the channels driving sibling similarity, we find that shared genes represent the most important background influence for individuals' occupational choice, explaining roughly half of sibling correlations. Our empirical analysis relies on a novel approach in entrepreneurship, using different sibling pair types to assess the correlation between shared genetic content and sibling correlations (Björklund et al., 2005), yet the results are similar to those obtained by classical twin studies. For example, Nicolaou and Shane (2010) document substantial heritability of entrepreneurial entry and intentions for both men and women in Sweden, while Nicolaou et al. (2008) and Zhang et al. (2009) find similar results for women in the United Kingdom and Sweden, respectively. While our results confirm the expectation that shared genes - as the earliest source of family influences - are particularly relevant for entrepreneurship, the importance of 'nature' by no means denies the importance of 'nurture' (Lindquist et al., 2015). In fact, shared genes overall explain less than a quarter of total variation in entrepreneurship entry, whereas environmental effects both inside and outside the family contribute most to explaining entrepreneurship outcomes. In addition, the similar results for unincorporated and incorporated entrepreneurship may point towards an underlying genetic mechanism affecting both outcomes, such as risk-taking behavior; alternatively, different elements of siblings' genetic architecture may be conducive to either type of entrepreneurship. Systematically disentangling genetic and environmental influences, as well as their variation across contexts, outcomes, and gender, remains an important task for future research.

The notion that entrepreneurial children tend to have entrepreneurial parents has provided the focus of substantial research in entrepreneurship and is remarkably robust (Parker, 2009). By discussing the different channels through which families and communities influence occupational choice, we argued that parental entrepreneurship represents an overly narrow lens for understanding the importance of families. Our finding that parental entrepreneurship explains between $6 \%$ and $14 \%$ of sibling correlations supports our argument and implies that in attempting to understand the role of families in entrepreneurship, researchers must cast a wider net beyond parental entrepreneurship. Yet, this channel represents one of the strongest family influences in our data, more important than neighborhood effects or parental resources. Role models at home prove to be very important for occupational choice, in line with previous research (Sørensen, 2007; Hoffmann et al., 2015; Lindquist et al., 2015). The coefficients underlying the explanatory power of parental entrepreneurship further support the role model interpretation, as the type of entrepreneurship pursued by parents is highly correlated with that pursued by children. Thus, not only are parental role models important, but they also operate along entrepreneurship type: exposure to incorporated, as opposed to self-employed, parents increases the salience or perceived attractiveness of incorporation as a career path. The smaller contribution of parental entrepreneurship to sibling correlations in entrepreneurial persistence and income suggests that the transmission of specific business human capital may not be the core channel through which parental entrepreneurship affects offspring, reinforcing the importance of the role-modeling channel.

Role model effects also motivate our investigation of neighborhoods (Giannetti and Simonov, 2009; Pistaferri et al., 2020). In our data, neighborhood effects explain between $3 \%$ and $8 \%$ of sibling correlations in entrepreneurship entry after controlling for parental characteristics. The share of other parents in the neighborhood who are entrepreneurs explains a third of these effects, providing evidence for the presence of neighborhood role models who offer children an opportunity to learn about entrepreneurship outside the household. Moreover, neighborhoods' outsized contribution to men's unincorporated entrepreneurship entry and persistence aligns with our hypothesis that some occupations - including farmers and various types of craftsmen - are male-dominated, geographically concentrated, and more likely to be pursued through unincorporated firms, such that the local industrial structure strongly shapes men's occupational choices and entrepreneurial engagement. This represents a novel finding in the entrepreneurship literature, and one that deserves rigorous future investigation, given its potential to explain the persistence of geographical variation in entrepreneurship.

Throughout the paper, we follow recent developments questioning the use of self-employment as a proxy for Schumpeterian entrepreneurship, and instead distinguish between unincorporated and incorporated entrepreneurs (Henrekson and Sanandaji, 2014, 2019; Levine and Rubinstein, 2017, 2018). These two types of entrepreneurship are theoretically distinct in their human and financial capital requirements and task content, and also differ in their empirical antecedents (Humphries, 2017). In our data, the incorporated score higher on cognitive and noncognitive skills (as well as own and parental education and earnings) than employees, who in turn score higher than unincorporated entrepreneurs. These results provide evidence for recent theories of selection into entrepreneurship from the tails of the ability distribution (Åstebro et al., 2011; Levine and Rubinstein, 2018). Moreover, we find that verbal, logical, spatial, technical, and leadership skills are more equally distributed for incorporated entrepreneurs, whereas skill dispersion is very similar for unincorporated entrepreneurs and employees. Thus, the 'jack-of-all-trades' conceptualization of entrepreneurship based on general skills (Lazear, 2005) seems appropriate mainly for incorporated entrepreneurs, who are expected to undertake a wider set of tasks and manage a larger workforce. This may also explain why we find a strong predictive power for leadership skills in incorporated entry and entrepreneurial income.

Beyond individual skill differences, we find that neighborhoods explain a higher share of sibling correlations in unincorporated than in incorporated entrepreneurship. While neighborhood role models are similarly important for both types of entrepreneurship, we hypothesize that the difference can be explained through the local industrial structure, whereby occupational or industry following drives unincorporated entrepreneurship, rather than the pursuit of a business opportunity per se (Aina and Nicoletti, 2018; Hvide and Oyer, 2018). ${ }^{13}$ Parental resources affect the two types of entrepreneurship differently, as they explain a higher share of sibling correlations in incorporation (7\%-12\%) relative to unincorporated entrepreneurship (2\%-7\%). This confirms the higher capital intensity of incorporated firms at entry, as already suggested by their larger presence in capital intensive industries, and shows

\footnotetext{
${ }^{13}$ In our accounting exercise, we also experimented with controlling for parents' (modal) industry. Parental industry explains around 4\% of sibling correlations in entrepreneurial entry, but up to $10.8 \%$ of brother correlations in Years unincorporated, in line with our occupational following argument. Nonetheless, we are cautious about interpreting these results, as parental industry may display substantial measurement error.
} 
that parental resources can be almost as important for meeting the requirements of incorporation as parental entrepreneurship. Parental education and income contribute even more to correlations in both unincorporated and incorporated income, suggesting that parental resources sustain these ventures' activity beyond entry. Overall, unincorporated and incorporated entrepreneurs appear as distinct venture types and reinforce the notion that incorporation serves as a proxy for the pursuit of growth-oriented, potentially Schumpeterian entrepreneurship (Henrekson and Sanandaji, 2019).

As predicted by our theoretical framework, sibling correlations and their drivers differ by gender. In unincorporated entrepreneurship, brother correlations are higher than sister correlations, reflecting the presence of sibling peers as well as stronger neighborhood effects. These influences may be correlated with the higher odds of occupational following in male-dominated, geographically concentrated occupations pursued through unincorporated firms, where skills may be easily passed on between family members. While brother and sister correlations in incorporated entry and performance are similar, parental resources explain a larger share of sister correlations. This finding may be due to women's difficulties in accessing finance (Marlow and Patton, 2005; Alsos et al., 2006; Coleman and Robb, 2009; Sauer and Wilson, 2016) or their higher risk aversion and higher safety net requirements (Robb and Watson, 2012). Unpacking these mechanisms presents an opportunity for future research and offers scholars the chance to deepen their understanding of the drivers of the entrepreneurship gender gap.

\subsection{Practical implications}

We believe our paper makes two practical contributions to research in entrepreneurship. First, we introduce sibling correlations as parsimonious, flexible, and transparent ways to estimate the total importance of family and community background. We hope that other researchers will make use of this method to produce comparisons across time and across countries. Second, we provide rich evidence on the differences between unincorporated and incorporated entrepreneurs, a dichotomy we believe researchers would benefit from adopting in future studies. For instance, these types of entrepreneurs contribute to inequality at different positions in the income distribution (Halvarsson et al., 2018) and exhibit distinct patterns regarding financial constraints, contributions to economic growth, or business cycle responses (Levine and Rubinstein, 2018; Henrekson and Sanandaji, 2019). Future studies could consider transitions between the different types of entrepreneurship in light of recent research on experimentation, which allows individuals to learn about their entrepreneurial ability in smallscale ventures before launching a growth-oriented firm (Folta et al., 2010; Manso, 2016).

Our results also hold implications for policy makers and entrepreneurs. Despite the undeniable importance of background influences, individual-specific effects explain the majority of variation in entrepreneurship outcomes, such that policies targeting entrepreneurship are not doomed to fail. Our findings are consistent with the idea that adolescents 'learn' about entrepreneurship through their family and community environment, which implies it should be possible to 'teach' entrepreneurship to young people (Huber et al., 2014; Elert et al., 2015; Pistaferri et al., 2020). Entrepreneurship education programs are thus more likely to be successful if they target individuals during their formative years and may prove more beneficial in fostering entrepreneurship. Our results also suggest that entrepreneurship education could be more effective by exposing young individuals to relevant role models and potentially by emphasizing leadership skills, especially for individuals without access to opportunities to learn about entrepreneurship (Eesley and Wang, 2017; Lyons and Zhang, 2018). These also represent areas that growth-oriented entrepreneurs should especially seek to develop as they build their human capital profile. Finally, policies designed to equip potential entrepreneurs with relevant skills may even generate a social multiplier effect if the behavior of a successfully treated person also affects the behavior of other family members, especially for future generations.

\subsection{Limitations and extensions}

Our study is not without limitations. First, when 'explaining' sibling similarities, we cannot claim to have presented a set of precise causal estimates. Instead, we view our theory and results as a way to point researchers towards those factors that can potentially explain the largest share of sibling similarities and that would benefit from future causal investigations. In addition, our estimates for the individual contribution of observable parental characteristics to sibling correlations represent upper bounds due to potential correlations between, for instance, parental income and parental entrepreneurship. To assess the extent of this potential problem, we also performed our accounting exercise jointly controlling for parental characteristics (as shown in Panel E of Online Appendix Table B.5, as opposed to Panels A-D). For unincorporated entrepreneurship, the sum of individual contributions of parental characteristics matches their joint contribution; for incorporation outcomes, the sum of individual contributions slightly overstates their joint contribution, suggesting that correlations between parental characteristics are more consequential for children's choice to become incorporated entrepreneurs. However, the underlying coefficients remain essentially unchanged in the joint model, strengthening our confidence that our estimates capture the importance of individual influences in an accurate manner.

Second, since we measure the degree to which siblings are similar, we cannot exclude the possibility that single-child families operate in a different manner and that lone children are influenced in different ways by family and community factors. ${ }^{14}$ Third, our results pertain to a highly developed economy, with specific cultural and economic traits, and notably egalitarian policies. Our results

\footnotetext{
${ }^{14}$ In unreported models, the intergenerational association between parents and children in entrepreneurship in single- and multiple- child families was very similar: 0.068 vs. 0.072 in unincorporated entrepreneurship and 0.132 and 0.102 in incorporated entrepreneurship, with very similar explanatory power. This suggests that parental entrepreneurship is broadly as important for children in single- and multiple- child families, and we expect this to be true for family background, more generally.
} 
may likely hold in the other Nordic countries, since we observe similar sibling correlations in other outcomes such as income and education across these countries (Solon, 1999; Björklund and Jäntti, 2011; Black and Devereux, 2011), but they may not apply elsewhere. For instance, sibling correlations in education and earnings are consistently higher in the U.S., suggesting a larger dependency of individual outcomes on family background, which likely extends to entrepreneurship. Systematically tracking changes over time (Björklund et al., 2009) and across countries (Schnitzlein, 2014) in sibling correlations in entrepreneurship and their drivers may provide important clues for the contribution of institutional environments towards erecting or alleviating constraints and barriers to entrepreneurship.

There may, of course, be factors other than those we address here that contribute to sibling similarities, such as parents' managerial ability, risk and time preferences, family values, social capital, or the presence of other family members (Laspita et al., 2012; Wyrwich, 2015; Edelman et al., 2016). Uncovering such variation is an interesting avenue for future research, though parts of these effects are arguably captured by the observable family characteristics we account for (e.g. parental risk preferences may determine parental entrepreneurship) and may have a genetic component as well. More generally, future research could attempt to address particular pathways of influence: how much do similarities in cognitive and non-cognitive ability (which we also consider here), educational achievement, choice of organizational hierarchies, obtaining a patent, etc., explain sibling correlations in entrepreneurship? Finally, researchers could also pay attention to how parents' deliberate intentions to foster entrepreneurship among their children (Jaskiewicz et al., 2015) affect sibling similarity.

\section{Conclusion}

In this paper, we argued that family and community background provide a salient context for the formation of individual entrepreneurial skills and preferences, extending far beyond the literature's narrow focus on parental entrepreneurship. Moreover, we drew on human capital accumulation theories to propose a 'hierarchy of family influences' in entrepreneurship that matches the timing of these influences, with earlier exposure translating into larger effects. Sibling correlations in Sweden confirm our hypotheses, suggesting that family and community background explain up to $45 \%$ of variation in entrepreneurship outcomes, with stronger effects for men and incorporation - a proxy for growth-oriented entrepreneurship. As the earliest influence, shared genes explain the largest share of sibling similarity, followed by the childhood and early youth influences of parental entrepreneurship, neighborhoods, and parental resources, and finally by a set of later and smaller influences, such as parental immigration, family structure, and sibling peers. Our results contribute to understanding the role of families in entrepreneurship and the distinct drivers of incorporation relative to unincorporated self-employment. While we view our results optimistically - as providing significant scope for individuals to learn how to become entrepreneurs - one should not ignore the large role of families in determining entrepreneurial outcomes. It is not clear that all young people with similar entrepreneurial skills have the same chances and opportunities to actually develop into entrepreneurs. As such, there may be a pool of entrepreneurial talent that society could dip into and develop; and in doing so increase both equality of opportunity and economic efficiency.

\section{CRediT authorship contribution statement}

Theodor Vladasel: Conceptualization, Methodology, Formal analysis, Writing - original draft, Writing - review \& editing. Matthew J. Lindquist: Conceptualization, Methodology, Data curation, Formal analysis, Writing - original draft, Writing - review \& editing. Joeri Sol: Conceptualization, Writing - original draft. Mirjam van Praag: Conceptualization, Writing - original draft.

\section{Online Appendix. Supplementary data}

Supplementary data to this article can be found online at https://doi.org/10.1016/j.jbusvent.2020.106017.

\section{References}

Aina, C., Nicoletti, C., 2018. The intergenerational transmission of liberal professions. Labour Econ. 51 (1), $108-120$.

Aldén, L., Hammarstedt, M., Neuman, E., 2017. All about balance? A test of the jack-of-all-trades theory using military enlistment data. Labour Econ. 49, 1):1-13. Aldrich, H.E., Kim, P.H., 2007. A life course perspective on occupational inheritance: self-employed parents and their children. Res. Sociol. Organ. 25 (1), $33-82$. Aldrich, H.E., Renzulli, L.A., Langton, N., 1998. Passing on privilege: resources provided by self-employed parents to their self-employed children. Res. Soc. Stratification Mobil. 16, 291-318.

Alsos, G.A., Isaksen, E.J., Ljunggren, E., 2006. New venture financing and subsequent business growth in men- and women-led businesses. Enterp. Theory Pract. 30 (5), $667-686$.

Altonji, J.G., Cattan, S., Ware, I., 2017. Identifying sibling influence on teenage substance use. J. Hum. Resour. 52 (1), 1-47.

Andersson, L., Hammarstedt, M., 2010. Intergenerational transmissions in immigrant self-employment: evidence from three generations. Small Bus. Econ. 34 (3), $261-276$.

Andersson, L., Hammarstedt, M., 2011. Transmission of self-employment across immigrant generations: the importance of ethnic background and gender. Rev. Econ. Househ. 9 (4), 555-577.

Arum, R., Müller, W. (Eds.), 2004. The Reemergence of Self-employment: A Comparative Study of Self-employment Dynamics and Social Inequality. Princeton University Press, Princeton, NJ.

Åstebro, T., Tåg, J., 2017. Gross, net, and new job creation by entrepreneurs. J. Bus. Ventur. Insights 8 (1), $64-70$.

Åstebro, T., Chen, J., Thompson, P., 2011. Stars and misfits: self-employment and labor market frictions. Manag. Sci. 57 (11), $1999-2017$.

Berglann, H., Moen, E.R., Røed, K., Skogstrøm, J.F., 2011. Entrepreneurship: origins and returns. Labour Econ. 18 (2), $180-193$.

Björklund, A., Jäntti, M., 2011. Intergenerational income mobility and the role of family background. In: Nolan, B., Salverda, W., Smeeding, T. (Eds.), The Oxford Handbook of Economic Inequality. Oxford University Press, Oxford, pp. 1-21. 
Björklund, A., Jäntti, M., 2012. How important is family background for labor-economic outcomes? Labour Econ. 19 (4), $465-474$.

Björklund, A., Jäntti, M., Solon, G., 2005. Influences of nature and nurture on earnings variation: a report on a study of various sibling types in Sweden. In: Bowles, S., Gintis, H., Osborne, M. (Eds.), Unequal Chances: Family Background and Economic Success. Russel Sage Foundation, New York, pp. $145-164$.

Björklund, A., Jäntti, M., Lindquist, M.J., 2009. Family background and income during the rise of the welfare state: brother correlations in income for Swedish men born 1932-1968. J. Public Econ. 93 (5-6), 671-680.

Björklund, A., Lindahl, L., Lindquist, M.J., 2010. What more than parental income, education and occupation? An exploration of what Swedish siblings get from their parents. B.E. J. Econ. Anal. Policy 10 (1).

Black, S.E., Devereux, P.J., 2011. Recent developments in intergenerational mobility. In: Ashenfelter, O., Card, D. (Eds.), Handbook of Labor Economics. 4B. Elsevier B.V, Amsterdam, pp. 1487-1541.

Blanchflower, D.G., Oswald, A.J., 1998. What makes an entrepreneur? J. Labor Econ. 16 (1), 26-60.

Bowen, D.D., Hisrich, R.D., 1986. The female entrepreneur: a career development perspective. Acad. Manag. Rev. 11 (2), $393-407$.

Certo, S.T., Withers, M.C., Semadeni, M., 2017. A tale of two effects: using longitudinal data to compare within- and between-firm effects. Strateg. Manag. J. 38 (7), 1536-1556.

Coleman, S., Robb, A., 2009. A comparison of new firm financing by gender: evidence from the Kauffman Firm Survey data. Small Bus. Econ. 33 (4), 397-411.

Colombier, N., Masclet, D., 2008. Intergenerational correlation in self employment: some further evidence from French ECHP data. Small Bus. Econ. 30 (4), $423-437$.

Conley, D., 2000. Sibship sex composition: effects on educational attainment. Soc. Sci. Res. 29 (3), 441-457.

Criaco, G., Sieger, P., Wennberg, K., Chirico, F., Minola, T., 2017. Parents' performance in entrepreneurship as a "double-edged sword" for the intergenerational transmission of entrepreneurship. Small Bus. Econ. 49 (4), 841-864.

Cunha, F., Heckman, J.J., 2007. The technology of skill formation. Am. Econ. Rev. 97 (2), 31-47.

Cunha, F., Heckman, J.J., 2008. Formulating, identifying and estimating the technology of cognitive and noncognitive skill formation. J. Hum. Resour. 43 (4), $738-782$.

Cunha, F., Heckman, J.J., Schennach, S.M., 2010. Estimating the technology of cognitive and noncognitive skill formation. Econometrica 78 (3), 883-931.

Dahl, M.S., Sorenson, O., 2012. Home sweet home: entrepreneurs' location choices and the performance of their ventures. Manag. Sci. 58 (6), $1059-1071$.

De Wit, G., Van Winden, F.A.A.M., 1989. An empirical analysis of self-employment in the Netherlands. Small Bus. Econ. 1 (4), $263-272$.

Dunn, T., Holtz-Eakin, D., 2000. Financial capital, human capital, and the transition to self-employment: evidence from intergenerational links. J. Labor Econ. 18 (2), $282-305$.

Edelman, L.F., Manolova, T., Shirokova, G., Tsukanova, T., 2016. The impact of family support on young entrepreneurs' start-up activities. J. Bus. Ventur. 31 (4), 428-448.

Edin, P.A., Fredriksson, P., Åslund, O., 2003. Ethnic enclaves and the economic success of immigrants: evidence from a natural experiment. Q. J. Econ. 118 (1), 329-357.

Eesley, C., Wang, Y., 2017. Social influence in career choice: evidence from a randomized field experiment on entrepreneurial mentorship. Res. Policy 46 (3), 636-650.

Elert, N., Andersson, F.W., Wennberg, K., 2015. The impact of entrepreneurship education in high school on long-term entrepreneurial performance. J. Econ. Behav. Organ. 111 (1), 209-223.

Elfenbein, D.W., Hamilton, B.H., Zenger, T.R., 2010. The small firm effect and the entrepreneurial spawning of scientists and engineers. Manag. Sci. 56 (4), 659-681.

Eriksson, K.H., Hjalmarsson, R., Lindquist, M.J., Sandberg, A., 2016. The importance of family background and neighborhood effects as determinants of crime. J. Popul. Econ. 29 (2), 219-262.

Evans, D.S., Jovanovic, B., 1989. An estimated model of entrepreneurial choice under liquidity constraints. J. Polit. Econ. 97 (4), $808-827$.

Fairlie, R.W., 1999. The absence of the African-American owned business. An analysis of the dynamics of self-employment. J. Labor Econ. 17 (1), 80-108.

Fairlie, R.W., Robb, A.M., 2007a. Families, human capital, and small business: evidence from the characteristics of business owners survey. Ind. Labor Relat. Rev. 60 (2), 225-245.

Fairlie, R.W., Robb, A.M., 2007b. Why are Black-owned businesses less successful than White-owned businesses? The role of families, inheritances, and business human capital. J. Labor Econ. 25 (2), 289-323.

Fairlie, R.W., Karlan, D., Zinman, J., 2015. Behind the GATE experiment: evidence on effects of and rationales for subsidized entrepreneurship training. Am. Econ. J. Econ. Pol. 7 (2), 125-161.

Folta, T.B., Delmar, F., Wennberg, K., 2010. Hybrid entrepreneurship. Manag. Sci. 56 (2), 253-269.

Giannetti, M., Simonov, A., 2009. Social interactions and entrepreneurial activity. J. Econ. Manag. Strateg. 18 (3), 665-709.

von Graevenitz, G., Harhoff, D., Weber, R., 2010. The effects of entrepreneurship education. J. Econ. Behav. Organ. 76, 90-112.

Grönqvist, E., Öckert, B., Vlachos, J., 2017. The intergenerational transmission of cognitive and noncognitive abilities. J. Hum. Resour. 52 (4), 887-918.

Guzman, J., Stern, S., 2016. The state of American entrepreneurship: new estimates of the quantity and quality of entrepreneurship for 15 US states, 1988-2014. In: NBER Working Paper, pp. 22095.

Halaby, C.N., 2003. Where job values come from: family and schooling background, cognitive ability, and gender. Am. Sociol. Rev. 68 (2), $251-278$.

Halvarsson, D., Korpi, M., Wennberg, K., 2018. Entrepreneurship and income inequality. J. Econ. Behav. Organ. 145 (1), $275-293$.

Hartog, J., van Praag, M., Van Der Sluis, J., 2010. If you are so smart, why aren't you an entrepreneur? Returns to cognitive and social ability: entrepreneurs versus employees. J. Econ. Manag. Strateg. 19 (4), 947-989.

Henrekson, M., Sanandaji, T., 2014. Small business activity does not measure entrepreneurship. Proc. Natl. Acad. Sci. 111 (5), $1760-1765$.

Henrekson, M., Sanandaji, T., 2019. Measuring entrepreneurship: do established metrics capture Schumpeterian entrepreneurship? Entrepreneurship Theory and Practice (forthcoming).

Hoffmann, A., Junge, M., Malchow-Møller, N., 2015. Running in the family: parental role models in entrepreneurship. Small Bus. Econ. 44 (1), $79-104$.

Holtz-Eakin, D., Joulfaian, D., Rosen, H.S., 1994a. Entrepreneurial decisions and liquidity constraints. RAND J. Econ. 25 (2), $334-347$.

Holtz-Eakin, D., Joulfaian, D., Rosen, H.S., 1994b. Sticking it out: entrepreneurial survival and liquidity constraints. J. Polit. Econ. 102 (1), 53-75.

Hopp, C., Minarikova, D., Speil, A., 2019. A chip off the old block? How parent-child interactions affect the intergenerational transmission of entrepreneurial intentions. J. Bus. Ventur. Insights 11 e00130.

Hout, M., Rosen, H., 2000. Self-employment, family background, and race. J. Hum. Resour. 35 (4), 670-692.

Huber, L.R., Sloof, R., Van Praag, M., 2014. The effect of early entrepreneurship education: evidence from a field experiment. Eur. Econ. Rev. 72 , 76-97.

Humphries, J.E., 2017. The Causes and Consequences of Self-employment Over the Life Cycle. Working Paper.

Hundley, G., 2006. Family background and the propensity for self-employment. Ind. Relat. 45 (3), 377-392.

Hurst, E., Lusardi, A., 2004. Liquidity constraints, household wealth, and entrepreneurship. J. Polit. Econ. 112 (2), $319-347$.

Hurst, E., Pugsley, B.W., 2011. What do small businesses do? Brook. Pap. Econ. Act. 43 (2), 73-128.

Hvide, H.K., Oyer, P., 2018. Dinner Table Human Capital and Entrepreneurship. NBER Working Paper, 24198.

Jaskiewicz, P., Combs, J.G., Rau, S.B., 2015. Entrepreneurial legacy: toward a theory of how some family firms nurture transgenerational entrepreneurship. J. Bus. Ventur. 30 (1), 29-49.

Joensen, J.S., Nielsen, H.S., 2018. Spillovers in education choice. J. Public Econ. 157 (1), 158-183.

Kacperczyk, A.J., 2013. Social influence and entrepreneurship: the effect of university peers on entrepreneurial entry. Organ. Sci. 24 (3), 664-683.

Kerr, W.R., Mandorff, M., 2015. Social Networks, Ethnicity, and Entrepreneurship. NBER Working Paper, 21597.

Laspita, S., Breugst, N., Heblich, S., Patzelt, H., 2012. Intergenerational transmission of entrepreneurial intentions. J. Bus. Ventur. 27 (4), 414-435.

Lazear, E.P., 2005. Entrepreneurship. J. Labor Econ. 23 (4), 649-680.

Lefgren, L., Lindquist, M.J., Sims, D., 2012. Rich dad, smart dad: decomposing the intergenerational transmission of income. J. Polit. Econ. 120 (2), $268-303$.

Lentz, B.F., Laband, D.N., 1990. Entrepreneurial success and occupational inheritance among proprietors. Can. J. Econ. 23 (3), $563-579$.

Lerner, J., Malmendier, U., 2013. With a little help from my (random) friends: success and failure in post-business school entrepreneurship. Rev. Financ. Stud. 26 (10), 


\section{T. Vladasel, et al.}

$2411-2452$.

Levine, R., Rubinstein, Y., 2017. Smart and illicit: who becomes an entrepreneur and do they earn more? Q. J. Econ. 132 (2), $963-1018$.

Levine, R., Rubinstein, Y., 2018. Talent, Wealth, and Entrepreneurship. Working Paper.

Lindquist, M.J., Sol, J., van Praag, C.M., 2015. Why do entrepreneurial parents have entrepreneurial children? J. Labor Econ. 33 (2), 269-296.

Lindqvist, E., Vestman, R., 2011. The labor market returns to cognitive and noncognitive ability: evidence from the Swedish enlistment. Am. Econ. J. Appl. Econ. 3 (1), 101-128.

Lyons, E., Zhang, L., 2018. Who does (not) benefit from entrepreneurship programs? Strateg. Manag. J. 39 (1), $85-112$.

Manso, G., 2016. Experimentation and the returns to entrepreneurship. Rev. Financ. Stud. 29 (9), $2319-2340$.

Marlow, S., Patton, D., 2005. All credit to men? Entrepreneurship, finance, and gender. Enterp. Theory Pract. 29 (6), 717-735.

Mazumder, B., 2008. Sibling similarities and economic inequality in the US. J. Popul. Econ. 21 (3), 685-701.

McGahan, A.M., Porter, M.E., 1997. How much does industry matter, really? Strateg. Manag. J. 18 (S1), 15-30.

Michelacci, C., Silva, O., 2007. Why so many local entrepreneurs? Rev. Econ. Stat. 89 (4), 615-633.

Mollick, E., 2012. People and process, suits and innovators: the role of individuals in firm performance. Strateg. Manag. J. 33 (9), $1001-1015$.

Nanda, R., Sørensen, J.B., 2010. Workplace peers and entrepreneurship. Manag. Sci. 56 (7), 1116-1126.

Nicolaou, N., Shane, S., 2010. Entrepreneurship and occupational choice: genetic and environmental influences. J. Econ. Behav. Organ. 76 (1), 3-14.

Nicolaou, N., Shane, S., Cherkas, L., Hunkin, J., Spector, T.D., 2008. Is the tendency to engage in entrepreneurship genetic? Manag. Sci. 54 (1), 167-179.

Nicolaou, N., Patel, P.C., Wolfe, M.T., 2017. Testosterone and tendency to engage in self-employment. Manag. Sci. 64 (4), 1477-1973.

Niittykangas, H., Tervo, H., 2005. Spatial variations in intergenerational transmission of self-employment. Reg. Stud. 39 (3), $319-332$.

Oosterbeek, H., van Praag, C.M., Ijsselstein, A., 2010. The impact of entrepreneurship education on entrepreneurship skills and motivation. Eur. Econ. Rev. 54 (3), $442-454$.

Özcan, S., Reichstein, T., 2009. Transition to entrepreneurship from the public sector: predispositional and contextual effects. Manag. Sci. 55 (4), 604-618.

Page, M.E., Solon, G., 2003. Correlations between brothers and neighboring boys in their adult earnings: the importance of being urban. J. Labor Econ. 21 (4), $831-855$.

Parker, S., 2009. The Economics of Entrepreneurship. Cambridge University Press, Cambridge, UK.

Pistaferri, L., Guiso, L., Schivardi, F., 2020. Learning entrepreneurship from other entrepreneurs. J. Labor Econ (forthcoming).

Polderman, T.J.C., Benyamin, B., Leeuw, C.A.D., Sullivan, P.F., Bochoven, A.V., Visscher, P.M., Posthuma, D., 2015. Meta-analysis of the heritability of human traits based on fifty years of twin studies. Nat. Genet. 47 (7), 702-709.

van Praag, C.M., Raknerud, A., 2014. The Entrepreneurial Earnings Puzzle. Evidence From Matched Person-Firm Data. Working Paper.

Roach, M., Sauermann, H., 2015. Founder or joiner? The role of preferences and context in shaping entrepreneurial orientations. Manag. Sci. 61 (9), $2160-2184$.

Robb, A.M., Watson, J., 2012. Gender differences in firm performance: evidence from new ventures in the United States. J. Bus. Ventur. 27 (5), 544-558.

Sauer, R.M., Wilson, T., 2016. The rise of female entrepreneurs: new evidence on gender differences in liquidity constraints. Eur. Econ. Rev. 86 (1), 73-86.

Schnitzlein, D.D., 2014. How important is the family? Evidence from sibling correlations in permanent earnings in the USA, Germany, and Denmark. J. Popul. Econ. 27 (1), 69-89.

Schoar, A., 2010. The divide between subsistence and transformational entrepreneurship. Innov. Policy Econ. 10 (1), 57-81.

Schoon, I., Duckworth, K., 2012. Who becomes an entrepreneur? Early life experiences as predictors of entrepreneurship. Dev. Psychol. 48 (6), $1719-1726$.

Solon, G., 1999. Intergenerational mobility in the labor market. In: Ashenfelter, O., Card, D. (Eds.), Handbook of Labor Economics. 3. Elsevier, Amsterdam, pp. $1761-1800$.

Sørensen, J.B., 2007. Closure and exposure: mechanisms in the intergenerational transmission of self-employment. In: Research in the Sociology of Organizations: The Sociology of Entrepreneurship. 25. pp. 83-124.

Tåg, J., Åstebro, T., Thompson, P., 2016. Hierarchies and entrepreneurship. Eur. Econ. Rev. 89 (1), $129-147$.

Tervo, H., 2006. Regional unemployment, self-employment and family background. Appl. Econ. 38 (9), $1055-1062$.

Vladasel, T., 2018. Same, but Different? Birth Order, Family Size, and Sibling Sex Composition Effects in Entrepreneurship. SOFI Working Paper, 8/2018. .

Wyrwich, M., 2015. Entrepreneurship and the intergenerational transmission of values. Small Bus. Econ. 45 (1), $191-213$.

Zhang, Z., Zyphur, M.J., Narayanan, J., Arvey, R.D., Chaturvedi, S., Avolio, B.J., Lichtenstein, P., Larsson, G., 2009. The genetic basis of entrepreneurship: effects of gender and personality. Organ. Behav. Hum. Decis. Process. 110 (2), 93-107.

Zunino, D., 2016. Are Genetics and Environment Substitutes or Complements in Affecting Entrepreneurial Choice? Working Paper. 